\title{
Summary of the LLNL Gasoline Spill Demonstration- Dynamic Underground Stripping Project
}

\author{
R. L. Newmark and R. D. Aines
}

April 3, 1995

This is an informal report intended primarily for internal or limited external distribution. The opinions and conclusions stated are those of the author and may or may not be those of the Laboratory.

Work performed under the auspices of the U.S. Department of Energy by the Lawrence Livermore National Laboratory under Contract W-7405-Eng-48.
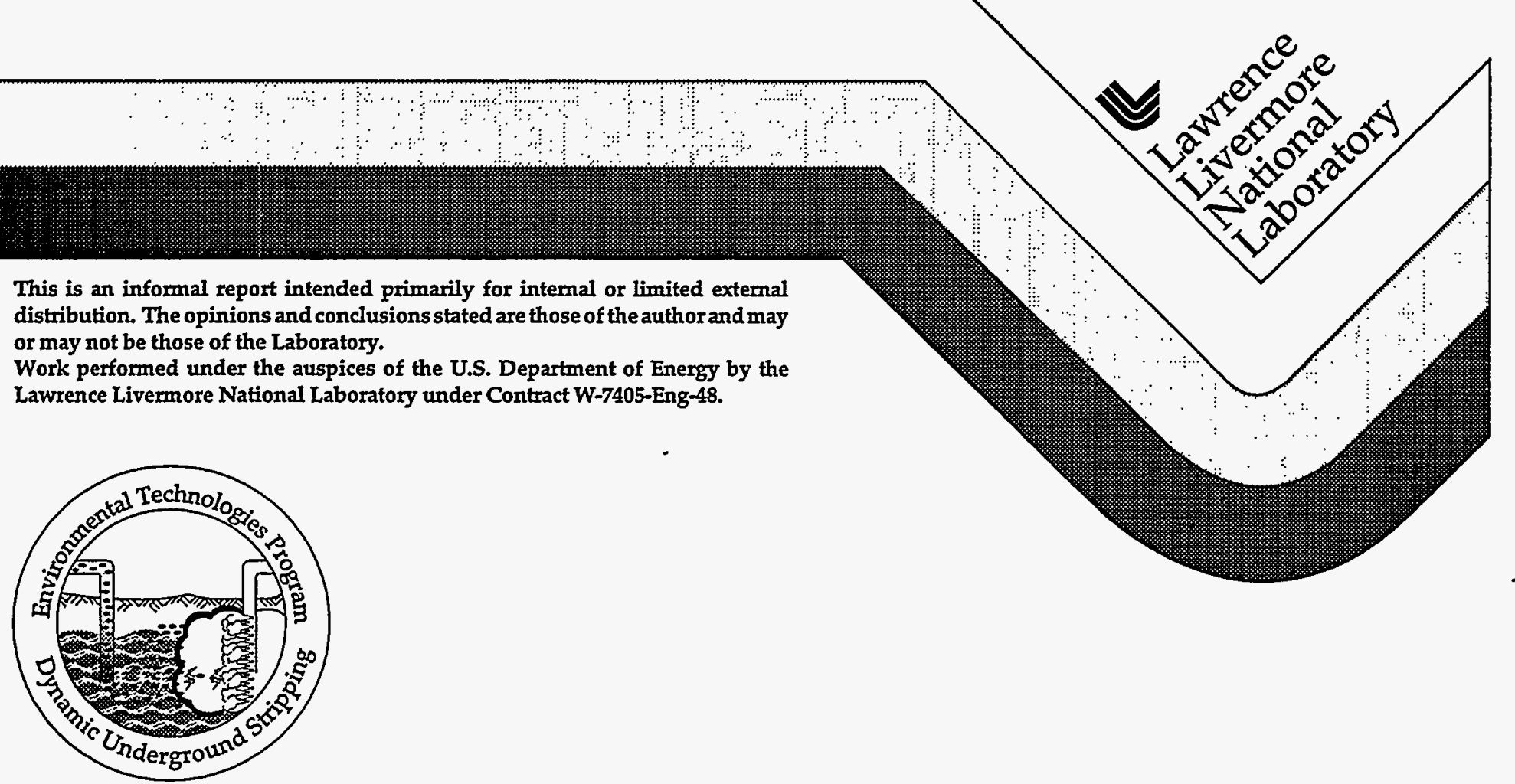


\section{DISCLAIMER}

This document was prepared as an account of work sponsored by an agency of the United States Government. Neither the United States Covernment nor the University of California nor any of their employees, makes any warranty, express or implied, or assumes any legal liability or responsibility for the accuracy, completeness, or usefulness of any information, apparatus, product, or process disclosed, or represents that its use would not infringe privately owned rights. Reference herein to any specific commercial product, process, or service by trade name, trademark, manufactures, or otherwise, does not necessarily constitute or imply its endorsement, recommendation, or favoring by the United States Government or the University of California. The views and opinions of authors expressed herein do not necessarily state or reflect those of the United States Covernment or the University of California, and shall not be used for advertising or product endorsement purposes.

This report has been reproduced directly from the best available copy.

Available to DOE and DOE contractors from the Office of Scientific and Technical Information P.O. Box 62, Oak Ridge, IN 37831

Prices available from (615) 576-8401, FTS 626-8401

Available to the public from the National Techrical Information Service

U.S. Department of Commerce 5285 Port Royal Rd. Springfield, VA 22161 


\section{DISCLAIMER}

Portions of this document may be illegible in electronic image products. Images are produced from the best available original document. 


\title{
Summary of the LLNL Gasoline Spill Demonstration- Dynamic Underground Stripping Project
}

\author{
R. L. Newmark and R. D. Aines \\ Environmental Technologies Program
}

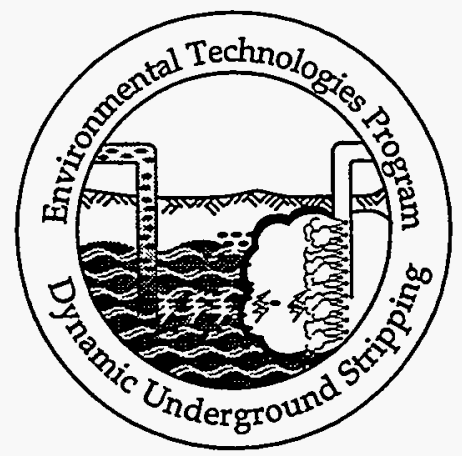

UCRL-ID-120416
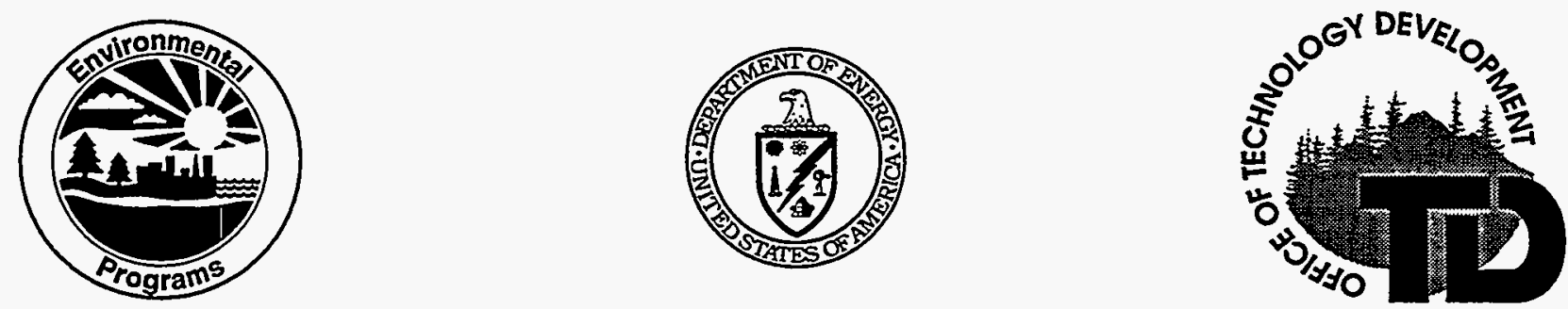


\section{Preface}

This report summarizes the four volumes of Dynamic Underground Stripping Project: LLNL Gasoline Spill Demonstration Report (Newmark, 1994a), which compiles the final reports for all the component activities of the Dynamic Underground Stripping demonstration at the LLNL gasoline spill site. The demonstration and cleanup efforts at that site from 1992 to early 1994 were funded jointly by the Department of Energy's Office of Technology Development and Office of Environmental Restoration. The full report combines those efforts into sections that reflect the major technical aspects of the project: Summary, Characterization, Operations, Monitoring, Predictive Modeling, and the Accelerated Removal and Validation (ARV) Project.

The Dynamic Underground Stripping demonstration at the LLNL gasoline spill site was extremely successful, and all of the project goals were met or exceeded. All aspects of this project reflect the integration of complementary technologies and process engineering. Some applications are obvious, such as the use of electrical heating and steam injection to heat the whole range of soil types. Others are not so obvious, such as the need to electrically isolate diagnostic and monitoring systems from the tremendous currents intentionally applied to the ground. The technical challenges in merely fielding these methods in a safe and effective manner at an operating industrial site were great. Safety in operation was a prime design parameter; our excellent safety record is one of the most satisfying accomplishments of this project. The combined achievements are greater than the sum of each individual component; this satisfies the requirements of true integration of method and application.

\section{Acknowledgments}

The full report, like the demonstration project itself, represents collaboration among investigators from many organizations, both between LLNL and other agencies and between organizations within LLNL. In particular, we acknowledge the contributions of Professor Kent Udell and the team members from the Environmental Restoration Center of the University of California at Berkeley, and the close collaboration between these individuals and LLNL researchers. The success of this project was largely due to the unique field-scale collaboration that utilized the complementary interests and research abilities of University and Laboratory researchers.

The successful demonstration of Dynamic Underground Stripping at the LINL gasoline spill site was made possible through the combined efforts of a great many people, with a broad range of expertise. We acknowledge the efforts of the mechanical and environmental technicians, procurement, construction and plant engineering personnel, and other staff without whose contributions (often in difficult conditions and inclement weather) this project would not have been possible. Students from the Environmental Center at University of California-Berkeley also provided essential support.

We gratefully acknowledge the support of the U.S. Department of Energy's Office of Environmental Management for this demonstration. The demonstration of innovative technologies requires that both experimental and compliance-driven cleanup operations needs be addressed. The efforts of the U.S. Department of Energy's representatives to reconcile often conflicting requirements made this project possible. In particular, we acknowledge the efforts of Clyde Frank, Pat Whitfield, Tom Crandall, Tom Anderson, Katie Hain, John Mathur, Kathy Angleberger, John Lehr, J. T. Davis, Richard Scott, Mike Brown and Bill Holman. Over its three-year history, this project utilized the resources of many, if not most, of the organizations at LLNL. In particular, we acknowledge the support of Jesse Yow, John Ziagos, Lee Younker, Bob Schock, J. I. Davis, Ann Heywood, Jay C. Davis, Alan Levy, Walt Sooy, Dennis Fisher, Harry Galles, Jens Mahler, and Bill McConachie.

This work was performed under the auspices of the U.S. Department of Energy by Lawrence Livermore National Laboratory under contract W-7405-Eng-48. The UC-Berkeley effort was funded in part by the National Instutue of Environmental Health Sciences under grant 3P42E504705.0251. 
The following is a list of contributing authors and their organizational affiliations.

\section{Lawrence Livermore National Laboratory}

Earth Sciences Division, Environmental Programs Directorate, Lawrence Livermore National Laboratory, Livermore, CA 94550

Roger D. Aines

O. Sierra Boyd

Charles R. Carrigan

Kevin C. Knauss

Kenrick H. Lee

Robin L. Newmark

John J. Nitao

Abelardo L. Ramirez

Jerry J. Sweeney

Defense Sciences Engineering Division, Electronics Engineering Department, Engineering Directorate, Lawrence Livermore National Laboratory, Livermore, CA 94550

Maurice A. Hernandez

Ray M. McNairy

Engineering Research Division of Electronics Engineering Department, Lawrence Livermore National Laboratory, Livermore, CA 94550

Jane Beatty

H. Michael Buettner

William Daily

Michael Wilt

Environmental Restoration Division, Environmental Protection Department, Lawrence Livermore National Laboratory, Livermore, CA 94550

Dorothy J. Bishop

Kenneth L. Carroll

C. Suzanne Chamberlain

Alan B. Copeland

Michael J. Dibley

Paula Krauter

J. C. Nelson-Lee

Maureen N. Ridley

Health and Ecological Assessment Division, Environmental Programs Directorate, Lawrence Livermore

National Laboratory, Livermore, CA 94550

Marina C. Jovanovich

Thomas J. Kulp

Kevin C. Langry

Roger E. Martinelli

Isotope Sciences Division, Chemistry and Material Sciences Directorate, Lawrence Livermore National Laboratory, Livermore, CA 94550

G. Bryant Hudson

New Technologies Engineering Division, Mechanical Engineering Department, Lawrence Livermore National Laboratory, Livermore, CA 94550

William H. Siegel 
Nuclear Test Engineering Division, Mechanical Engineering Department, Lawrence Livermore National Laboratory, Livermore, CA 94550

John Carbino

Technical Support and Policy Development Division, Hazards Control Department, Lawrence Livermore National Laboratory, Livermore, CA 94550

James Martin

\section{University of California at Berkeley}

Department of Mechanical Engineering, University of California at Berkeley, 6165 Etcheverry Hall, Berkeley, CA 94720

Ron Goldman

Kent M. Kenneally

Kent S. Udell

Materials Science and Mineral Engineering Department, University of California at Berkeley, Berkeley, CA 94720
A. E. Adenekan
T. W. Patzek

\section{Oak Ridge National Laboratory}

Health Sciences Research Division, Oak Ridge National Laboratory, Oak Ridge, TN 37831-6113

Tye E. Barber

Walter G. Fisher

Eric A. Wachter

\section{Weiss Associates}

Weiss Associates, Inc., Emeryoille, CA

Charles Noyes

Everett A. Sorensen

\section{Infraseismic Systems, Inc.}

Infraseismic Systems, Inc., 4630 Easton Drive Suite 5, Bakersfield, CA 93309

Roger J. Hunter

Richard F. Reinke 


\section{Contents}

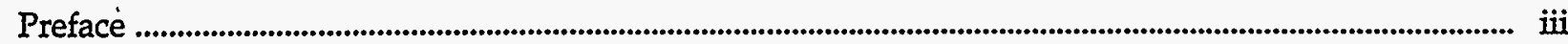

Acknowledgments .......................................................................................................................................................... iii

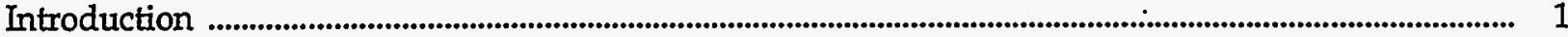

Results of First Full-Scale Test .....................................................................................................................

Based on Three Technologies .............................................................................................................................. 2

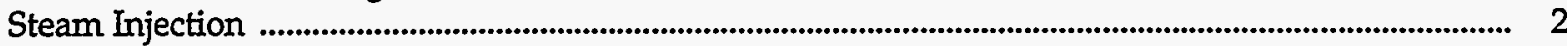

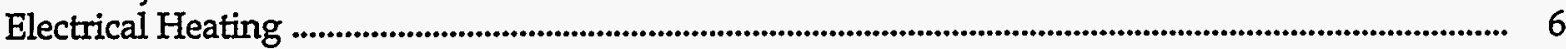

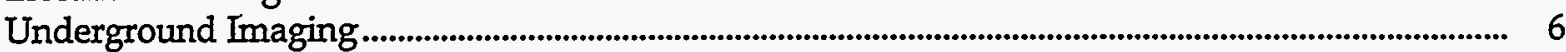

The LLNL Gasoline Spill Site .................................................................................................................................... 6

Cleanup Operations........................................................................................................................................................ 9

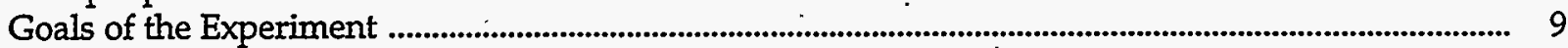

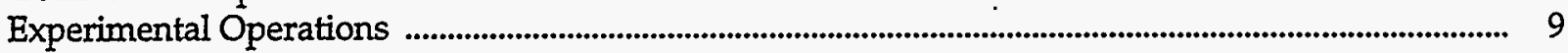

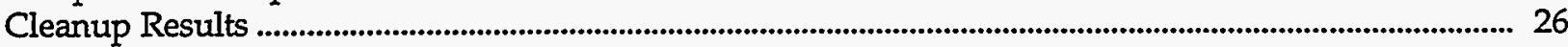

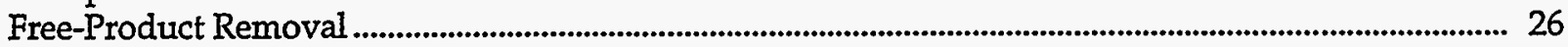

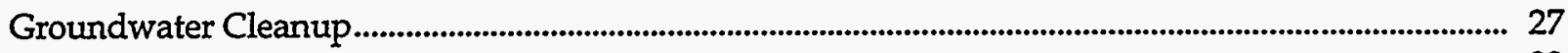

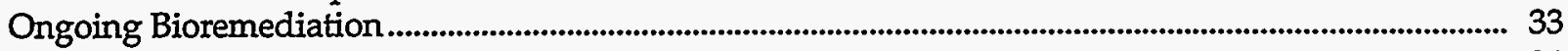

Conclusions from the Gasoline Spill Site Demonstration ................................................................................ 34

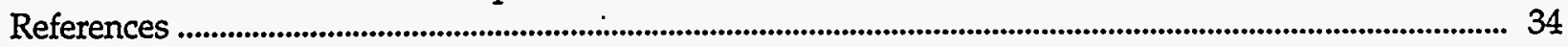




\title{
Summary of the LLNL Gasoline Spill Demonstration- Dynamic Underground Stripping Project
}

\author{
Introduction
}

Underground spills of volatile hydrocarbons (solvents or fuels) can be difficult to clean up when the hydrocarbons are present both above and below the water table and are found in relatively impermeable clays (Figure 1). Years of groundwater pumping may not completely remove the contamination. Researchers at Lawrence Livermore National Laboratory (LLNL) and the College of Engineering at the University of California at Berkeley (UCB) have collaborated to develop a technique called Dynamic Underground Stripping to remove localized underground spills in a relatively short time. The U.S. Department of Energy's Office of Environmental Restoration and Waste Management has sponsored a full-scale demonstration of this technique at the LLNL gasoline spill site.

Although it has been known for years that accumulations of separate-phase organics represent the most serious cause of groundwater pollution (National Research Council, 1994; MacDonald and Kavanaugh, 1994), their very low solubility in water has made them very hard to remove by the classic method of pumping out groundwater and treating it at the surface. Similarly, the principal natural mechanism for groundwater restoration, biological metabolism of the contaminant, usually will not work in very concentrated contaminant because of the toxic nature of the organic. (Bacteria typically metabolize organics dissolved in water, not free organic liquids.)

When highly concentrated contamination is found above the standing water table, vacuum extraction has been very effective at both removing the contaminant and enhancing biological remediation through the addition of oxygen. Below the water table, however, these advantages cannot be obtained. For such sites where the contamination is too deep for excavation, there are currently no widely applicable cleanup methods.

Dynamic Underground Stripping removes separate-phase organic contaminants below the water table by heating the subsurface above the boiling point of water, and then removing both contaminant and water by vacuum extraction. The high temperatures both convert the organic to vapor and enhance other removal paths by increasing diffusion and eliminating sorption. Because this method uses rapid, high-energy techniques in cleaning the soil, it requires an integrated system of underground monitoring and imaging methods to control and evaluate the process in real time.

\section{Results of First Full-Scale Test}

We conducted the initial testing of the combined thermal and monitoring/imaging methods of Dynamic Underground Stripping at the site of a gasoline spill at the Lawrence Livermore National Laboratory. This site was chosen because several thousand gallons of gasoline were trapped up to 30 feet below the water table (Figure 2), mimicking the behavior of heavy solvents such as trichloroethylene (TCE).

This first full-scale test of Dynamic Underground Stripping at the LLNL gasoline site was extremely successful. Results completed in December 1993 indicate that the process is more than 60 times as effective as the conventional pump-and-treat process now being used at 300 designated Superfund Sites to treat contamination below the water table, and is 15 times as effective as vacuum extraction in the vadose zone (above the water table) (Figure 3). The LLNL site was previously under treatment by vacuum extraction from a central extraction well (Nicholls et al., 1988; Thorpe et al., 1990; Cook et al., 1991). From August 1988 to December 1991, more than 1900 gallons of gasoline were removed from the vadose zone. However, the extraction rate had dropped to about 2 gallons per day by 1991 . No large groundwater removal actions were undertaken at that point; but because of the low solubility of gasoline in water (about 10,000-ppb total hydrocarbons were observed in the groundwater), a pumping rate of 50 gallons/minute would have only removed about 0.5 gallon of gasoline per day. To continue the cleanup, the vacuum venting operation was halted, and replaced by the Dynamic Underground Stripping technique. 


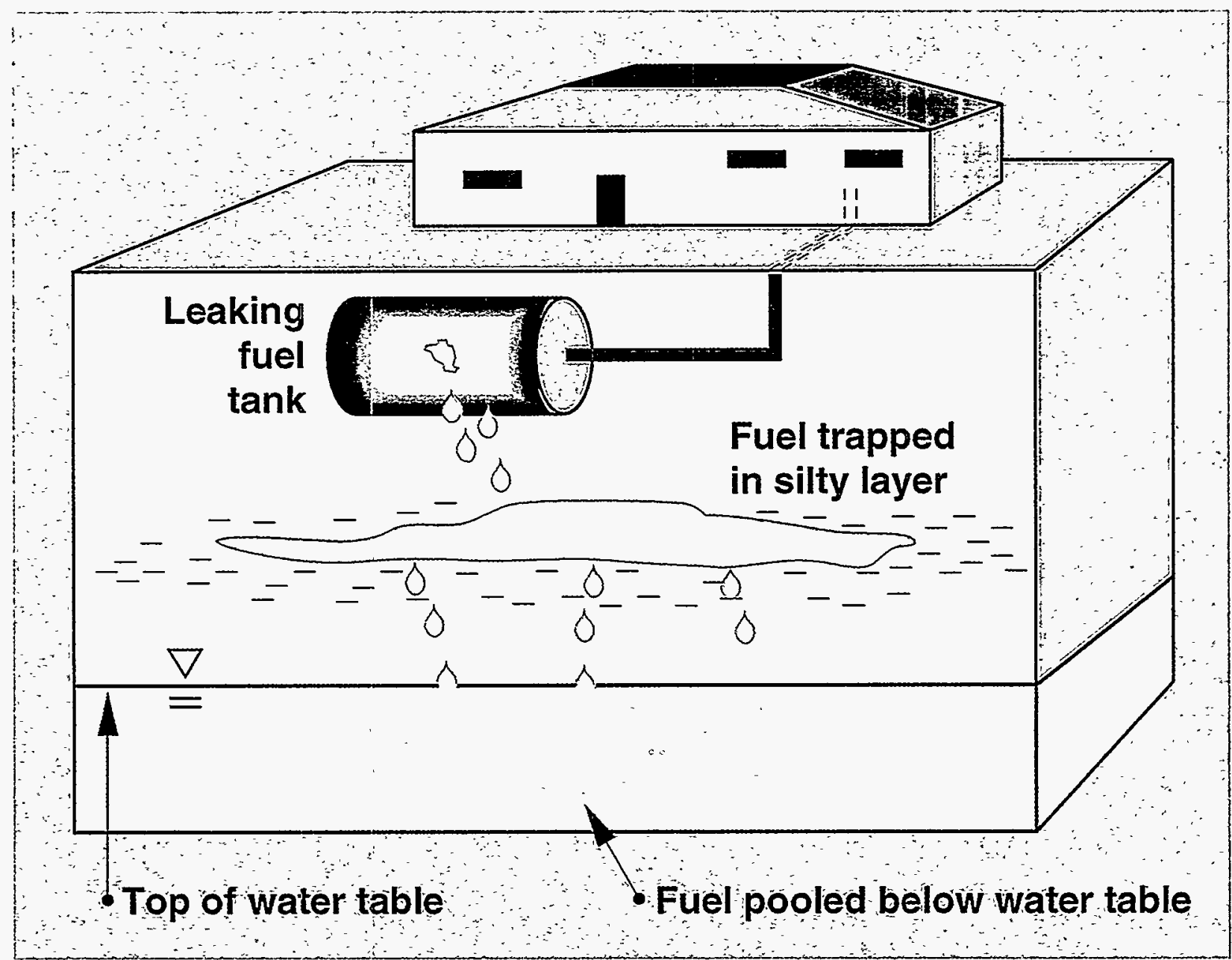

Figure 1. A plume of organic liquid forming beneath a leaking underground storage tank. This behavior is typical of a heary organic solvent such as trichloroethylene (TCE). Some of the liquid may be trapped in layers of low-permeability soil above the water table. The remainder will form a pool below the water table, as shown here. Lighter contaminants such as gasoline can be trapped below water by movement of the water table.

During the 21 weeks of operation over the course of one year, Dynamic Underground Stripping removed more than 7600 gallons of gasoline trapped in soil (significantly more than the 6200 gallons estimated to be present), both above and below the water table, with separatephase contamination extending to $>120 \mathrm{ft}$ deep. The maximum removal rate was 250 gallons of gasoline a day. The process was limited only by the ability to treat the contaminated substance at the surface. Actual field experience indicates that the process costs $\$ 60-\$ 70$ a cubic yard. Approximately $100,000 \mathrm{yd}^{3}$ were cleaned.

\section{Based on Three Technologies}

Dynamic Underground Stripping relies on three integrated technologies; steam injection, electrical heating, and underground imaging (Figure 4).

\section{Steam Injection}

Steam is pumped into injection wells, heating the contaminated earth to $100^{\circ} \mathrm{C}$. Steam drives contaminated water toward the extraction wells where it is pumped to the surface. When the steam front encounters contamination, volatile organic compounds are distilled from the hot soil and are moved to the steam/groundwater interface, where they condense. Vacuum extraction after full steaming of the contaminated zone continues to remove residual contaminants. The steam injection/vacuum extraction technique was developed at UCB (Udell and Stewart, 1989, 1990; Udell et al., 1991; Udell, 1994d). The steam system and operational design used here are described in Siegel (1994) and Udell (1994c). Predictive 


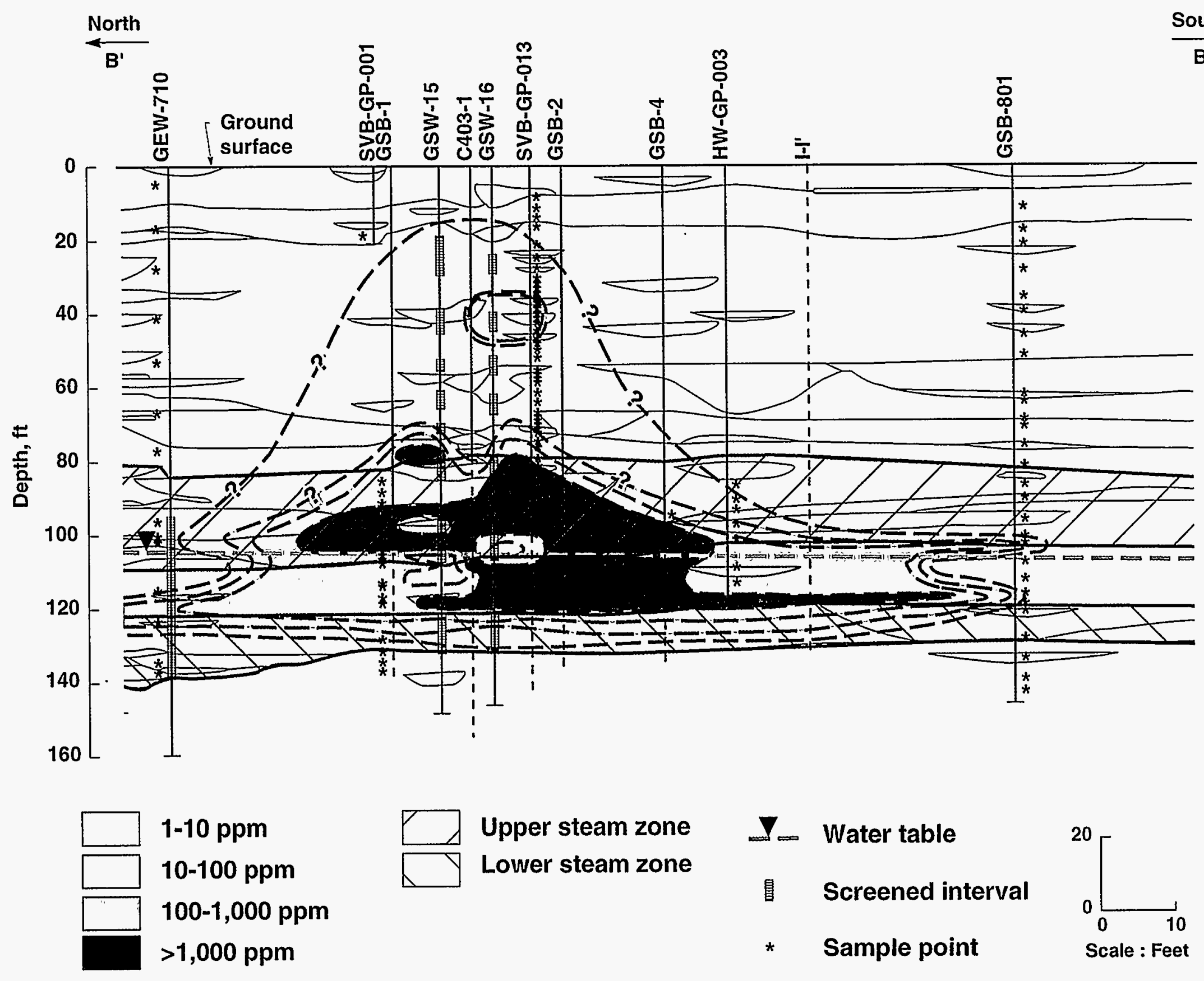

Figure 2. Cross section showing an approximation of the gasoline contamination at the treatment site before Dynamic Underground Stripping began. The darker areas represent higher concentrations; the darkest indicates free-product gasoline. The dashed line denotes the level of the water table. (From Bishop et al., 1994). 


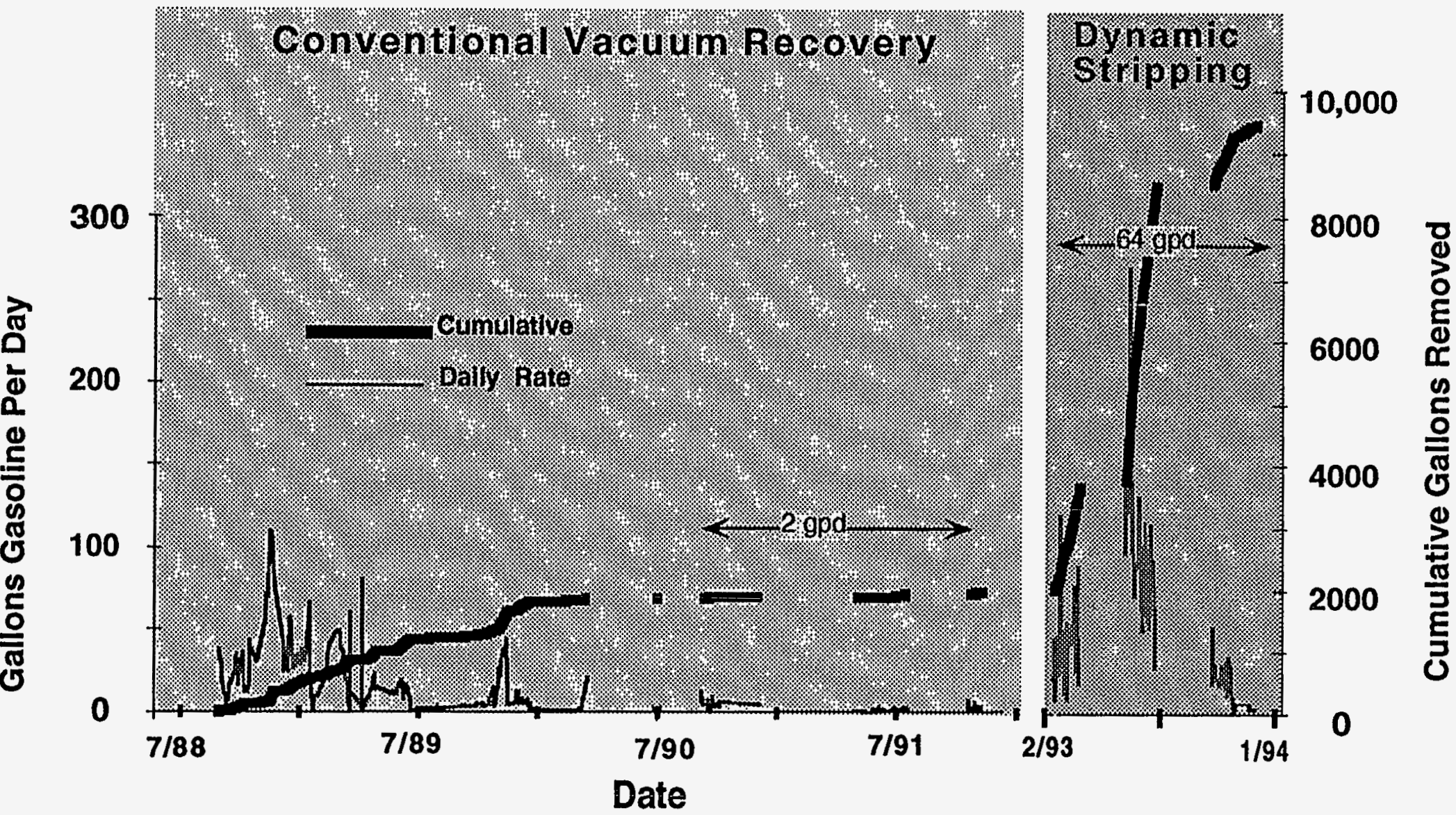

Figure 3. Recovery rates during Dynamic Underground Stripping compared to conventional methods fielded at the LLNL gasoline spill site. Vacuum extraction, begun in late 1988, stabilized at a recovery rate of 2 gallons of gasoline per day after an initially higher rate (Cook et al., 1991). Conventional pump and treat combined with vacuum extraction, tested just before the start of Dynamic Underground Stripping (not shown), showed an initial additional recovery rate of $0.5 \mathrm{gal} /$ day gasoline in pumped water, for a total conventional recovery of $2.5 \mathrm{gal} / \mathrm{day}$. Dynamic Underground Stripping averaged 64 gal/day during the year in which the 21 weeks of operations were conducted. Dynamic Underground Stripping removed vadose zone contamination at about 15 times the rate of conventional methods, and groundwater contamination at greater than 60 times the conventional rate. 


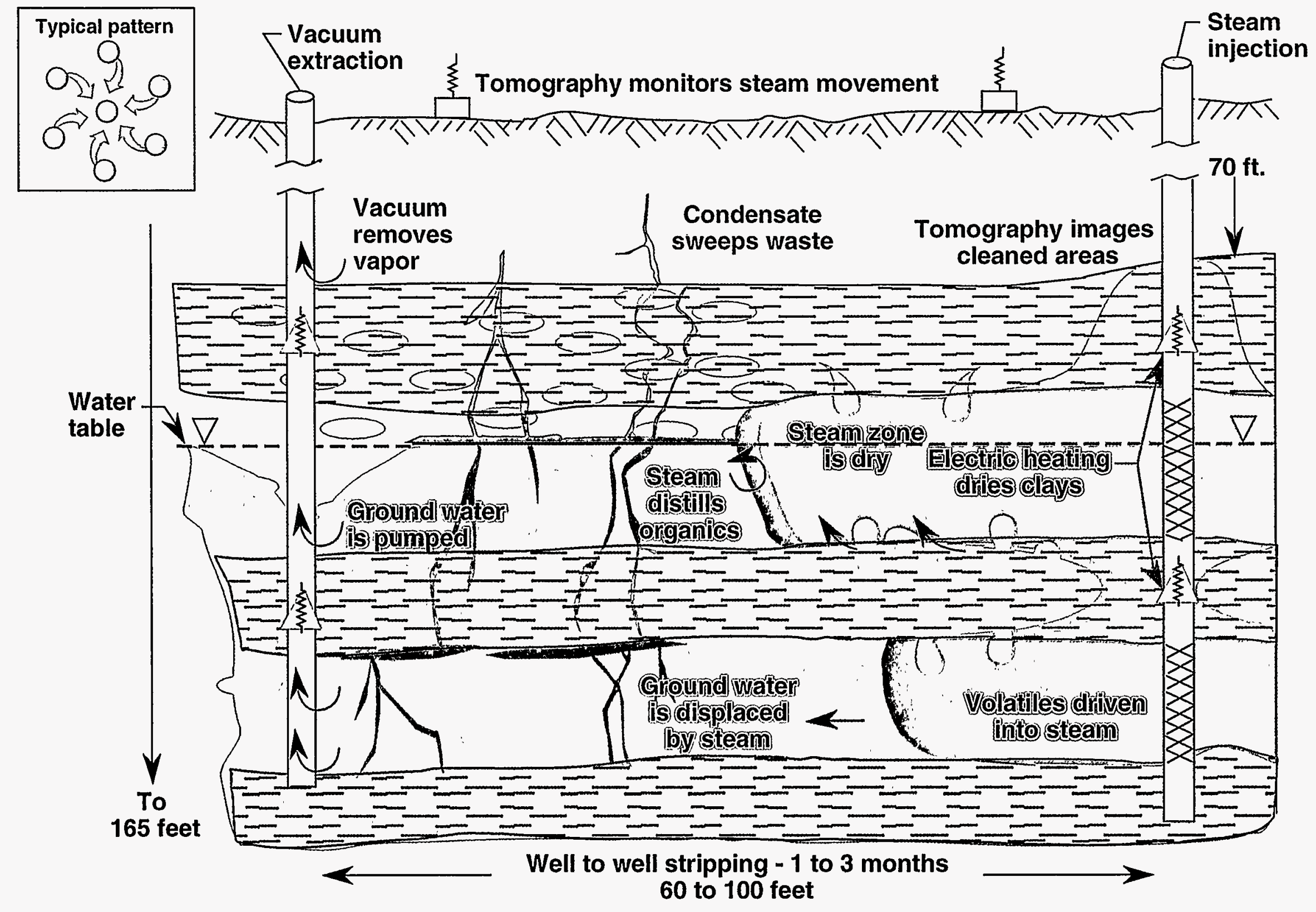

Figure 4. The Dynamic Underground Stripping process. Steam drives contaminated groundwater toward extraction wells and then heats the soil to distill organics. Electrical heating dries and distills impermeable clays that the steam cannot readily penetrate. Geophysical techniques monitor the process. The process operates both above and below the water table (dashed line) and is particularly economically attractive for free-product removal (solid green). 
calculations of the operational characteristics and recovery efficiency of steam injection as applied at the LLNL gasoline spill site are given by Udell (1994b), Kenneally (1994), Adenekan and Patzek (1994), and Lee (1994).

\section{Electrical Heating}

This technique heats clay and fine-grained sediments and causes water and contaminants trapped within the soils to vaporize and be forced into the steam-swept zones, where vacuum extraction removes them. Electrical heating is ideally suited for tight, clay-rich soil and/or nearsurface (less than 20 feet) cleanups. It is an effective complement to steam injection, because it cleans the thick, less permeable zones that the steam does not penetrate well.

Electrical heating has been used in a number of configurations in enhanced petroleum recovery (e.g., Chute et al., 1987; Chute and Vermeulen, 1988); the three-phase system used here was designed at LLNL (Buettner and Daily, 1994a; McGee et al., 1994). Details of the electrical heating construction and operational design used here are given by Siegel (1994), and the results of the preheat phase are found in Buettner and Daily (1994b). Our predictive and diagnostic modeling capability for electrical heating is presented by Carrigan and Nitao (1994). Sweeney et al. (1994) give details of the post-steam electrical heating process conducted during this experiment.

\section{Underground Imaging}

To monitor the Dynamic Underground Stripping process, we used geophysical imaging methods to map the boundary between the heated zones and the cooler surrounding areas. Electrical resistance tomography (ERT) has proven to be the best imaging technique for near-real-time images of the heated zones (Newmark, 1992, 1994c; Ramirez et al., 1993; Vaughn et al., 1993). This technique is necessary for controlling the thermal process and for monitoring the water movement. Details of the use of ERT at the gasoline spill site are given by Newmark (1994b), and Ramirez et al. (1994). Tiltmeters provided additional information regarding the shape of the steamed zone (Hunter and Reinke, 1994), while detailed temperature and geophysical logs provided extremely accurate assessments of the degree of penetration and the complex heating of the numerous heterogeneous formation layers (Newmark, 1994b; Goldman and Udell, 1994; Boyd et al., 1994).

\section{The LLNL Gasoline Spill Site}

We conducted an experimental application of the Dynamic Underground Stripping technique during 1993 at the LLNL gasoline spill site. This is the former site of the Laboratory's filling station; fueling operations at this location date back to the 1940s, when the LLNL site was a U.S. Naval air station. It is located in the center of an industrial area-the Laboratory's shipping and receiving yard. A county road runs along the south side, and major underground utility lines run through the site.

Previous characterization results were combined with an extensive set of measurements taken during the installation of 22 process and monitoring boreholes at the site. Details of the site characterization are given in Bishop et al. (1994). This characterization showed that an estimated 6200 gallons of gasoline were present within our target treatment area (both above and below the water table) (Figure 2). Gasoline was trapped up to $30 \mathrm{ft}$ below the water table because of a rise in the water table after the spill occurred, with the gasoline held below water by capillary forces in the soil. The soils at the site are alluvial, ranging from very fine silt/clay layers to extremely coarse gravels, with unit permeabilities ranging over several orders of magnitude. There are two principal permeable zones, one above and one below the water table, which is located at $100 \mathrm{ft}$. In between the permeable zones, straddling the water table, is a 10-15-ft-thick silty/clay layer of low permeability, which was also heavily contaminated (Nelson-Lee, 1994).

The targeted volume was intended to include all of the free-phase gasoline at the site, and was a distorted cylinder about $120 \mathrm{ft}$ in diameter and $80 \mathrm{ft}$ high, extending from a depth of $60 \mathrm{ft}$ to a depth of $140 \mathrm{ft}$ (Figure 5). Later results indicated that two small areas of gasoline probably existed outside the treatment area, possibly from separate spills.

Six steam injection/electric-heating wells were placed to surround the free product in an irregular circle determined by the shape of the free product; three additional electric heating wells were placed near the center of the spill. These were not part of the original design, but 


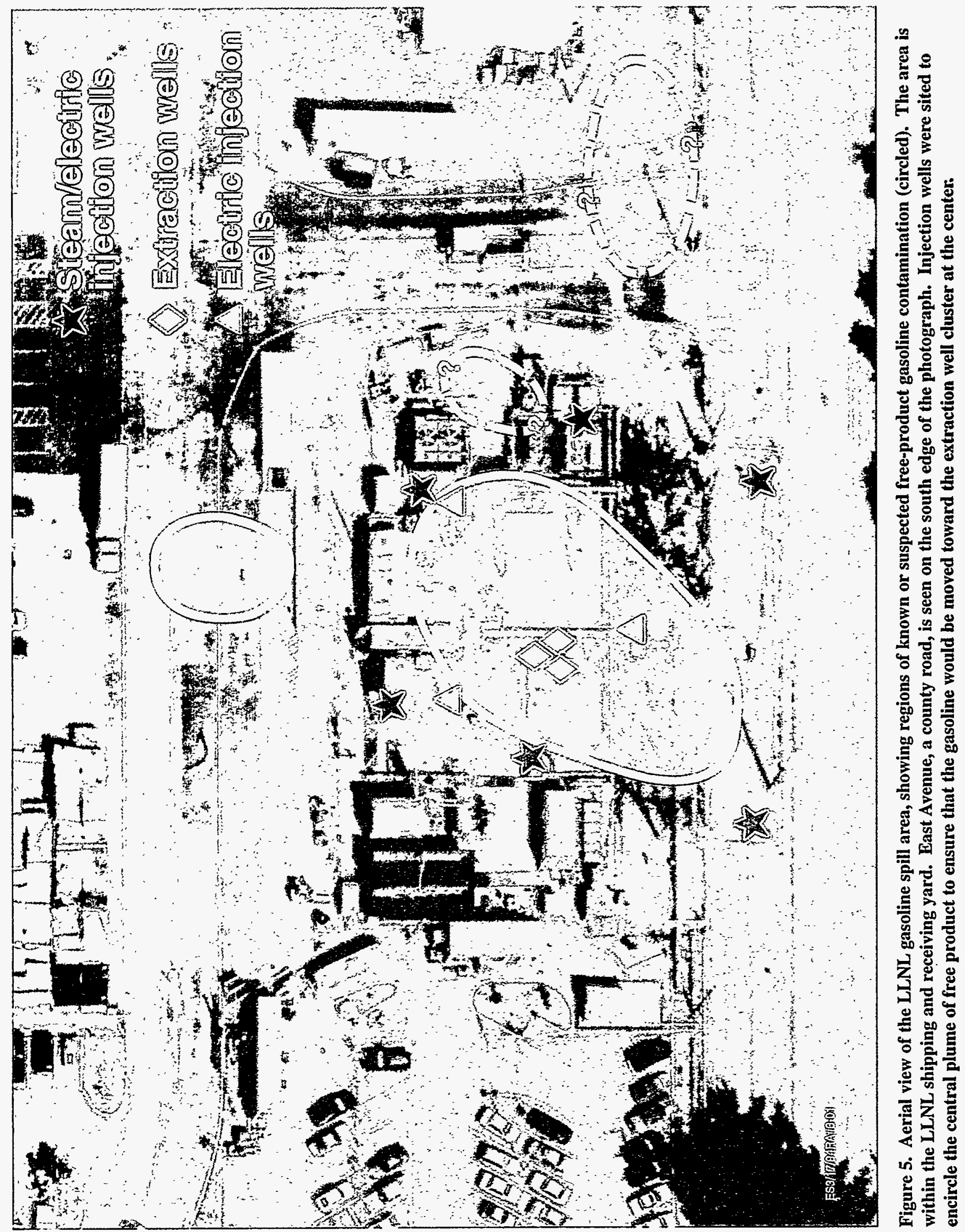


were required when the free-product zone was discovered to be larger than anticipated during the drilling of the injection wells. Each injection well was initially center-punched with a smalldiameter hole for characterization. The discovery of unexpected free product in two of them had minimal impact; the holes were completed as monitoring locations, and new injection wells were drilled farther from the spill center. We placed eleven monitoring/imaging wells within and outside the target area to provide control of the heating processes (Figure 6).

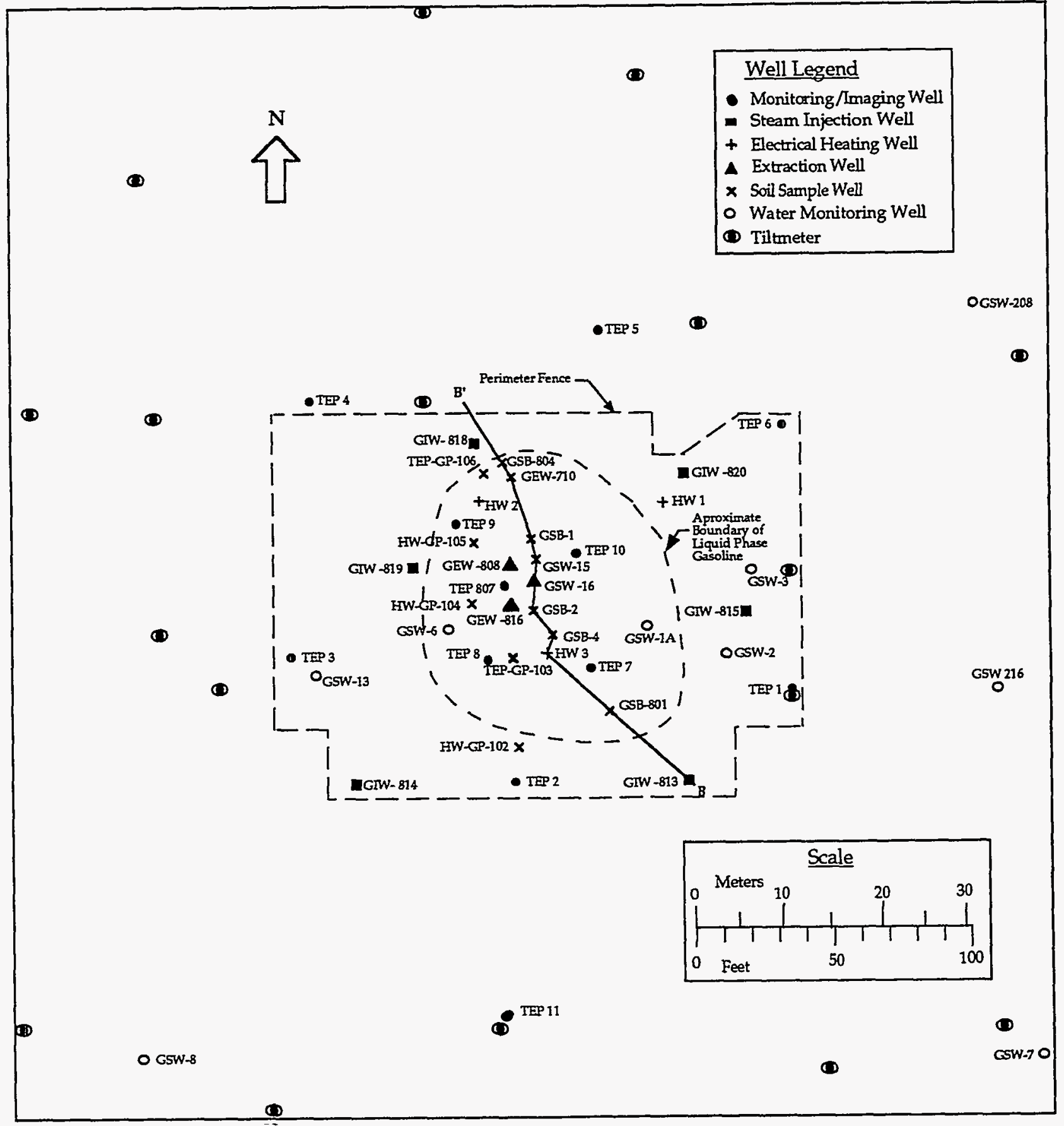

Figure 6. Map of the LLNL gasoline spill site, showing the location of wells referred to in this summary. The location of cross section B-B' (Figure 2) is shown. (Not all pre-Dynamic Underground Stripping well and boring locations are shown.) This map shows a slightly larger area than Figure 5. 


\section{Cleanup Operations}

\section{Goals of the Experiment}

Dynamic Underground Stripping was originally designed for the removal of separate-phase organic liquids from highly contaminated areas both above and particularly below the water table. The goals of the first application of the method were:

1. To determine the effectiveness of the process in removing free product.

2. To evaluate the effectiveness of the monitoring methods for controlling heat input and mapping heated zones.

3. To examine whether any deleterious effects (such as dispersal of contaminant) might occur.

4. To demonstrate the necessary engineering and operational practices required for effective and safe operation of this high-energy technique.

All goals were met and the site and process were turned over to the Laboratory's site remediation team (funded by DOE's EM 40) for final site cleanup (Sweeney et al., 1994).

\section{Experimental Operations}

Operations at the site were conducted in four distinct phases:

(1) Electric Preheating: November and December 1992

(2) First Steam Pass: February 1993

(3) Second Steam Pass: May-July 1993 (drill-back characterization followed)

(4) Polishing Operations (accelerated removal and validation): October-December 1993

Table 1 summarizes the project history.

The electrical preheat of the site began in November 1992, before the treatment facility was completed. No extraction data are therefore available from this phase. The electrical preheat phase is described in detail by Buettner and Daily (1994b). The 1-MW electrical system operated at a maximum power output of about $800 \mathrm{~kW}$. The chief monitoring methods used during the electrical preheating were temperature measurements and ERT. Temperatures were measured using both fixed thermocouples in individual boreholes and, for continuous logs, an infrared-sensor system in the 112 -in.-diameter fiberglass monitoring/ imaging wells (Newmark, 1994b; Goldman and Udell, 1994).
The goal of an average $20^{\circ} \mathrm{C}$ temperature rise in the clay zones was achieved; some of the clay layers were heated to a maximum of $70^{\circ} \mathrm{C}$ (Figure 7). The effects of this phase on the extraction of gasoline were not tested, but several of the groundwater monitoring wells on the site showed increases in the concentration of gasoline components, indicating that free-phase gasoline was being mobilized in the vicinity (Figure 8). Gasoline concentrations in these wells had been decreasing previously, apparently due to localized bioremediation or venting resulting from the increased air circulation to the borehole area.

Steam injection began in early February 1993 into the lower of two steam zones (permeable layers) using a 24,000 lb/hr (50 gallons water/ minute, energy approximately $8 \mathrm{MW}$ ) naturalgas-fired, skid-mounted boiler (Figure 9). Siegel (1994) describes the steam operations in detail. Steam injection rapidly heated the permeable zones to above the boiling point of water, and initial steam breakthrough to the extraction wells occurred in 12 days (Figure 10). During the first steam pass, it was learned that, although a bank of cold, free-product gasoline may precede the steam front to the extraction wells, it contains only a small fraction of the recovered gasoline (Jovanovich et al., 1994; Aines et al., 1994) (Figure 11). None of the 1700 gallons recovered during the first steam pass could unambiguously be associated with the liquid front ahead of the steam. The great majority of the gasoline came out after a steam zone was fully established, and the extraction continued without further steam injection. The reduced vapor pressure forces residual pore fluids and contaminants to boil. At this point, the forced boiling generated large amounts of water and gasoline in the vapor stream, and our potential removal rates greatly exceeded our dual-bed activated-carbon trailer's design limit of about 25 gallons/day. During the planned shutdown following the first steam pass, the vapor treatment system was redesigned to increase capacity (Sorensen and Siegel, 1994).

The monitoring and imaging systems utilized at the gasoline spill site provided excellent control of the steam injection process (Newmark, 1994b; Goldman and Udell, 1994; Ramirez et al., 1994; Boyd et al., 1994). Initial steam breakthrough to the extraction wells occurred in only 12 days; each subsequent breakthrough occurred sooner as 
Table 1. Project history of the Dynamic Underground Stripping project LLNL gasoline spill site cleanup.

\begin{tabular}{|c|c|c|c|}
\hline Phase & Dates & Objectives & Accomplishments \\
\hline $\begin{array}{l}\text { Vacuum Extraction, } \\
\text { Vadose Zone } \\
\text { EM } 40 \text { Operations }\end{array}$ & $\begin{array}{l}9 / 88 \text { to } \\
12 / 91\end{array}$ & $\begin{array}{l}>\text { Extract vadose gasoline } \\
\text { contamination. } \\
>\text { Evaluate extraction } \\
\text { effectiveness. }\end{array}$ & $\begin{array}{l}>\text { Pilot Test.permitting received. } \\
>2000 \text { gallons removed } \\
>\text { Biological activity confirmed }\end{array}$ \\
\hline $\begin{array}{l}\text { Clean Site } \\
\text { Engineering Test } \\
\text { EM } 50\end{array}$ & $\begin{array}{l}2 / 91 \text { to } \\
9 / 91\end{array}$ & $\begin{array}{l}>\text { Demonstrate } \\
\text { establishment of steam } \\
\text { zone below water table. } \\
>\text { Evaluate and optimize } \\
\text { monitoring, imaging } \\
\text { systems. } \\
>\text { Optimize resistance } \\
\text { heating electrode } \\
\text { design. } \\
>\text { Evaluate personnel and } \\
\text { environmental safety. }\end{array}$ & $\begin{array}{l}>10,000 \mathrm{yd}^{3} \text { steam zone } \\
\text { established below water table } \\
\text { with no steam rise. } \\
>\text { ERT, thermal logging, and } \\
\text { tiltmeters demonstrated, chosen } \\
\text { for gas pad use. } \\
>\text { Individual electrode capacity } \\
\text { raised from } 20 \mathrm{~kW} \text { to } 200 \mathrm{~kW} \text {. } \\
>\text { Safe procedures established for } \\
\text { personnel; no detrimental } \\
\text { environmental effects. }\end{array}$ \\
\hline $\begin{array}{l}\text { Electrical Pre-Heat } \\
\text { EM50 operations, } \\
\text { EM } 40 \text { Treatment } \\
\text { Facility F } \\
\text { construction }\end{array}$ & $\begin{array}{l}11 / 92 \text { to } \\
1 / 93\end{array}$ & $\begin{array}{l}>\text { Raise temperature of } \\
\text { clay/silt layers } 20^{\circ} \mathrm{C} \text { so } \\
\text { conductivity always } \\
\text { above steam- } \\
\text { temperature gravel } \\
\text { zones. } \\
>\text { Test electrical safety at } \\
\text { high current in } \\
\text { industrial area. } \\
>\text { Optimize electrical } \\
\text { heating methods. }\end{array}$ & $\begin{array}{l}>\text { Clay pre-heating accomplished. } \\
>\text { Maximum heating to } 70^{\circ} \mathrm{C} \text { in } \\
\text { clay layer. } \\
>\text { Safety measures and procedures } \\
\text { adequate. } \\
>850 \mathrm{~kW} \text { continuous power } \\
\text { achieved. } \\
>\text { Nighttime operations with } \\
\text { daylight construction of } \\
\text { treatment facility. }\end{array}$ \\
\hline $\begin{array}{l}\text { 1st Steam Pass } \\
\text { Joint EM40/EM50 } \\
\text { operations }\end{array}$ & $\begin{array}{l}2 / 93 \text { to } \\
3 / 93\end{array}$ & $\begin{array}{l}>\text { Heat target zones to steam } \\
\text { temperature. } \\
>\text { Optimize } \\
\text { monitoring/control } \\
\text { methods. } \\
>\text { Evaluate treatment } \\
\text { procedures and facility. } \\
>\text { Quantify possible } \\
\text { deleterious effects } \\
\text { (such as contaminant } \\
\text { spreading). } \\
>\text { Demonstrate safe } \\
\text { handling of steam and } \\
\text { hot gasoline effluent. }\end{array}$ & $\begin{array}{l}>\text { Upper and Lower steam zones } \\
\text { heated to boiling point. } \\
>\text { ERT established as control system } \\
\text { with } 12 \text { hr turnaround on } 10 \\
\text { planes/day. } \\
>\text { Non-contact thermal logger } \\
\text { demonstrated with no } \\
\text { hysteresis, } 100^{\circ} \mathrm{C} / 2 \mathrm{ft} \\
\text { gradients. } \\
>\text { Gasoline found to be mainly } \\
\text { recovered in vapor phase, } \\
\text { greatly exceeding capacity. No } \\
\text { liquid phase free-product } \\
\text { recovered. } \\
>\text { No spreading of contaminant to } \\
\text { outer monitoring wells/ } \\
>\text { Safe handling of steam and hot } \\
\text { gasoline. } \\
>1700 \text { gallons gasoline removed. }\end{array}$ \\
\hline
\end{tabular}


Table 1. (Continued.)

\begin{tabular}{|c|c|c|c|}
\hline $\begin{array}{l}\text { 2nd Steam Pass } \\
\text { Joint EM40/EM50 } \\
\text { operations }\end{array}$ & $\begin{array}{l}5 / 93 \text { to } \\
7 / 93\end{array}$ & $\begin{array}{l}>\text { Operate re-designed vapor } \\
\text { treatment system with } \\
\text { 10x capacity of first } \\
\text { pass. } \\
>\text { Optimize } \\
\text { steaming/recovery } \\
\text { technique to maximize } \\
\text { vacuum recovery. } \\
>\text { Heat zones which were } \\
\text { insufficiently heated in } \\
\text { first pass. } \\
>\text { Accurately measure } \\
\text { gasoline flux in vapor } \\
\text { and condensate paths, } \\
\text { reduce uncertainty in } \\
\text { total recovery rate, } \\
\text { continuously monitor } \\
\text { gasoline flux. }\end{array}$ & $\begin{array}{l}>100,000 \text { yd }^{3} \text { heated to boiling } \\
\text { point. } \\
>\text { Recovery rates in excess of } 250 \\
\text { gal/day achieved. } \\
>\text { Tiltmeters used for imaging of } \\
\text { horizontal extent of steam } \\
\text { zones from individual wells. } \\
>\text { Most cool zones from 1st pass } \\
\text { fully heated to steam } \\
\text { temperature (one "cold spot" } \\
\left.\text { remained at } 80^{\circ} \mathrm{C}\right) . \\
>\text { Fuxes measured to } \pm 10 \% \\
\text { accuracy, continuous } \\
\text { monitorng systems } \\
\text { demonstrated. } \\
>4600 \text { gallons gasoline removed. }\end{array}$ \\
\hline $\begin{array}{l}\text { Post-Test Drill-Back } \\
\text { Characterization }\end{array}$ & $\begin{array}{l}7 / 93 \text { to } \\
9 / 93\end{array}$ & $\begin{array}{l}>\text { Measure soil } \\
\text { concentration changes } \\
\text { along six-hole cross- } \\
\text { section } \\
>\text { Ascertain from soil } \\
\text { concentrations whether } \\
\text { spreading had occurred } \\
\text { (outside original } \\
\text { contamination) } \\
>\text { Evaluate process } \\
\text {. effectiveness. } \\
>\text { Examine possible changes } \\
\text { to soil. } \\
>\text { Examine effects on } \\
\text { existing microbial } \\
\text { gasoline-degrading } \\
\text { ecosystem. }\end{array}$ & $\begin{array}{l}\text { > Soil concentrations reduced } \\
\text { dramatically. } \\
>\text { No spreading of contaminant; } \\
\text { only inward motion seen. } \\
>\text { Vadose zone completely clean } \\
\text { (<1 ppm) } \\
>\text { Saturated zone contaminant } \\
\text { remained around extraction } \\
\text { cluster only. } \\
>\text { No significant soil changes. } \\
>\text { Active microbial ecosystems at all } \\
\text { locations and soil temperatures } \\
\text { up to } 90^{\circ} \mathrm{C} \text {, makeup varies by } \\
\text { soil temperature. }\end{array}$ \\
\hline $\begin{array}{l}\text { Accelerated } \\
\text { Recovery and } \\
\text { Validation (ARV) }\end{array}$ & $\begin{array}{l}10 / 93 \text { to } \\
1 / 94\end{array}$ & $\begin{array}{l}\text { > Remove remaining free } \\
\text { product, especially in } \\
\text { cool -zone. } \\
>\text { Make use of existing heat } \\
\text { and high extraction } \\
\text { rates to continue } \\
\text { removal. } \\
>\text { Electrically heat clay/silt } \\
\text { zones to enhance } \\
\text { removal. } \\
>\text { Test sparging, injection } \\
\text { well extraction. }\end{array}$ & $\begin{array}{l}>\text { Remaining free-product gasoline } \\
\text { removed (1000 gallons). } \\
>\text { Ground water concentrations of } 5 \\
\text { of } 6 \text { regulated compounds } \\
\text { reduced to } \mathrm{MCL} \text {. } \\
>\text { Benzene down to } 100 \mathrm{ppb} \text { in } \\
\text { ground water. } \\
>\text { Sparging monitored with noble- } \\
\text { gas tracers. } \\
>\text { Electrical heating maintained site } \\
\text { soil temperatures during } \\
\text { extraction. }\end{array}$ \\
\hline
\end{tabular}


Well TEP- 007

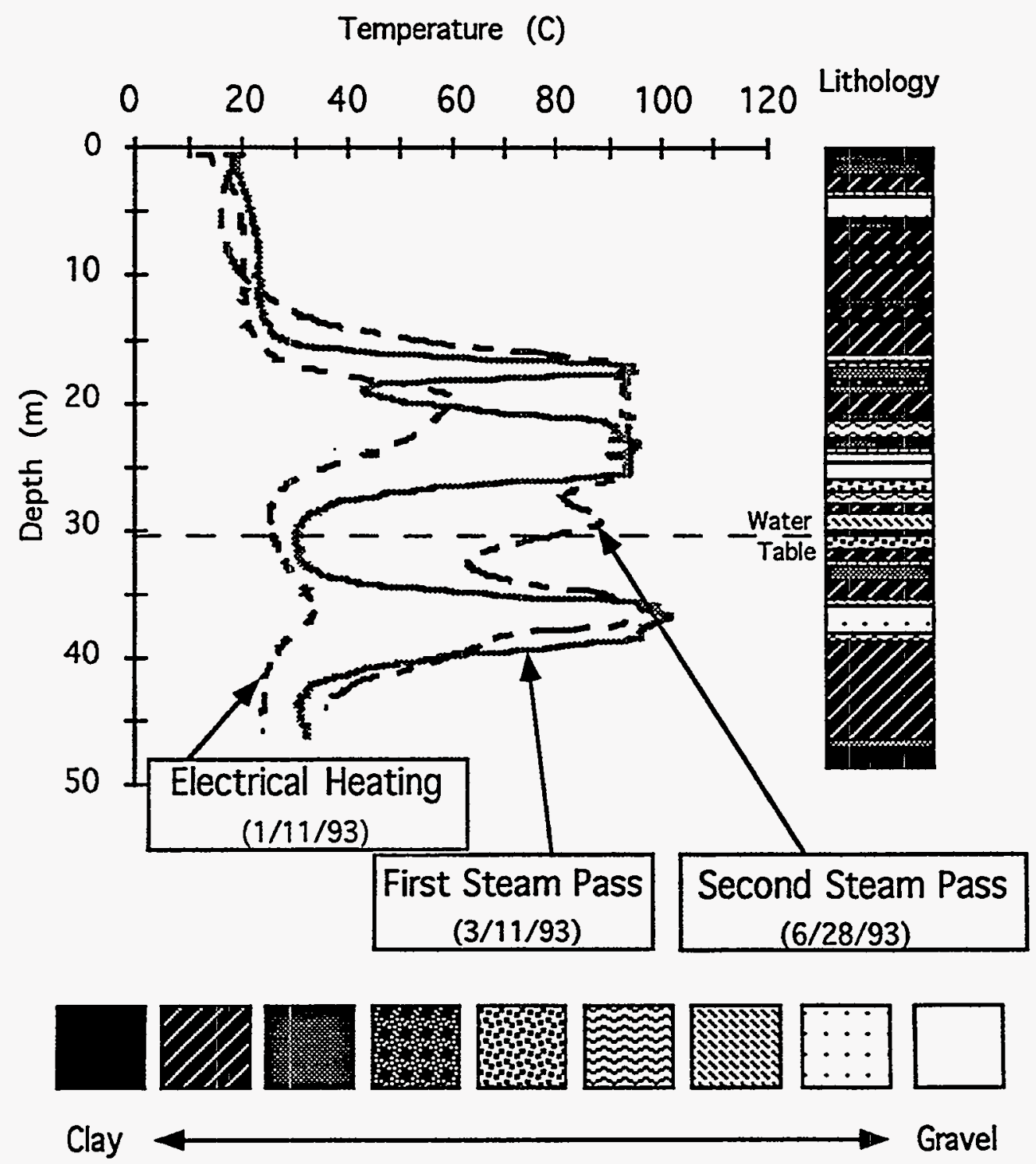

Figure 7. Temperature logs from a monitoring well inside the ring of injection wells, along with the lithology. These logs show electrical heating of the clay-rich layers during the electrical preheat, steam passing through the most permeable layers during the first steam pass, and conductive heating of and later penetration by steam into less permeable layers during the second steam pass. (From Newmark, 1994b).

the formation gained heat. This made the day-today process monitoring critical in order to ensure that the correct amount of steam was injected to drive contaminant to the center without adding excessive amounts of steam outside the pattern. Each of the twelve injection ports (two each in six wells) would inject a different amount of steam at a given pressure, ranging from $600 \mathrm{lb} / \mathrm{hr}$ to one well that would apparently have taken the entire output of the boiler had we so permitted. This range is expected in such a heterogeneous site, but it requires that the location and size of the steam zones be measured in situ, not merely calculated from injection volumes.

Temperature measurements made both with fixed thermocouples in the field and with the 


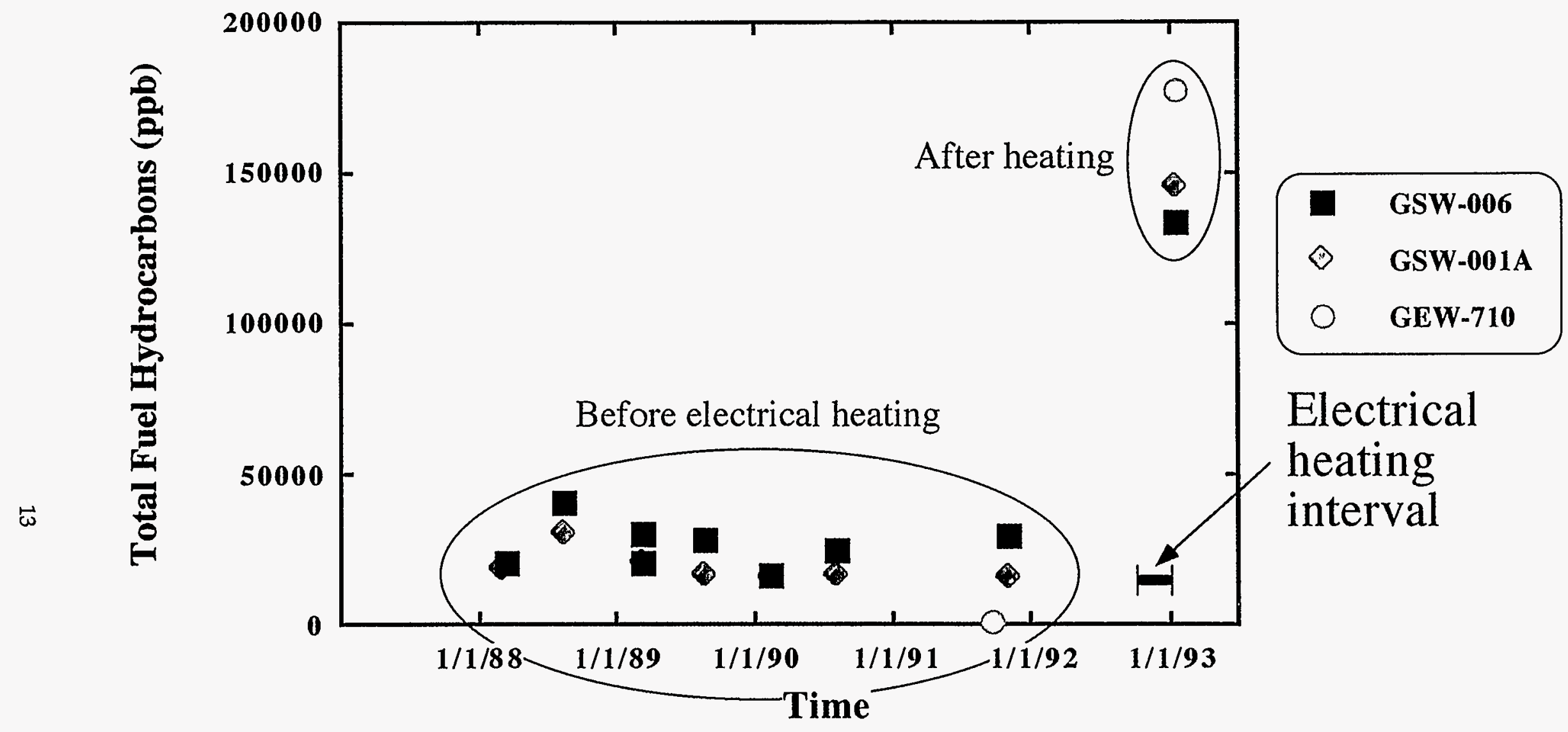

HMB/LLNL/11-1-93

Figure 8. Chemical signatures of groundwater in monitoring wells in the central gasoline spill area. Before electrical heating, total fuel hydrocarbon concentrations (TFH) were below $50,000 \mathrm{ppb}$ and generally decreasing, most probably due to localized enhanced bioremediation in the vicinity of the boreholes. After electrical heating, high TFH concentrations were found, indicating contact with free-product gasoline (Buettner and Daily, 1994b). 


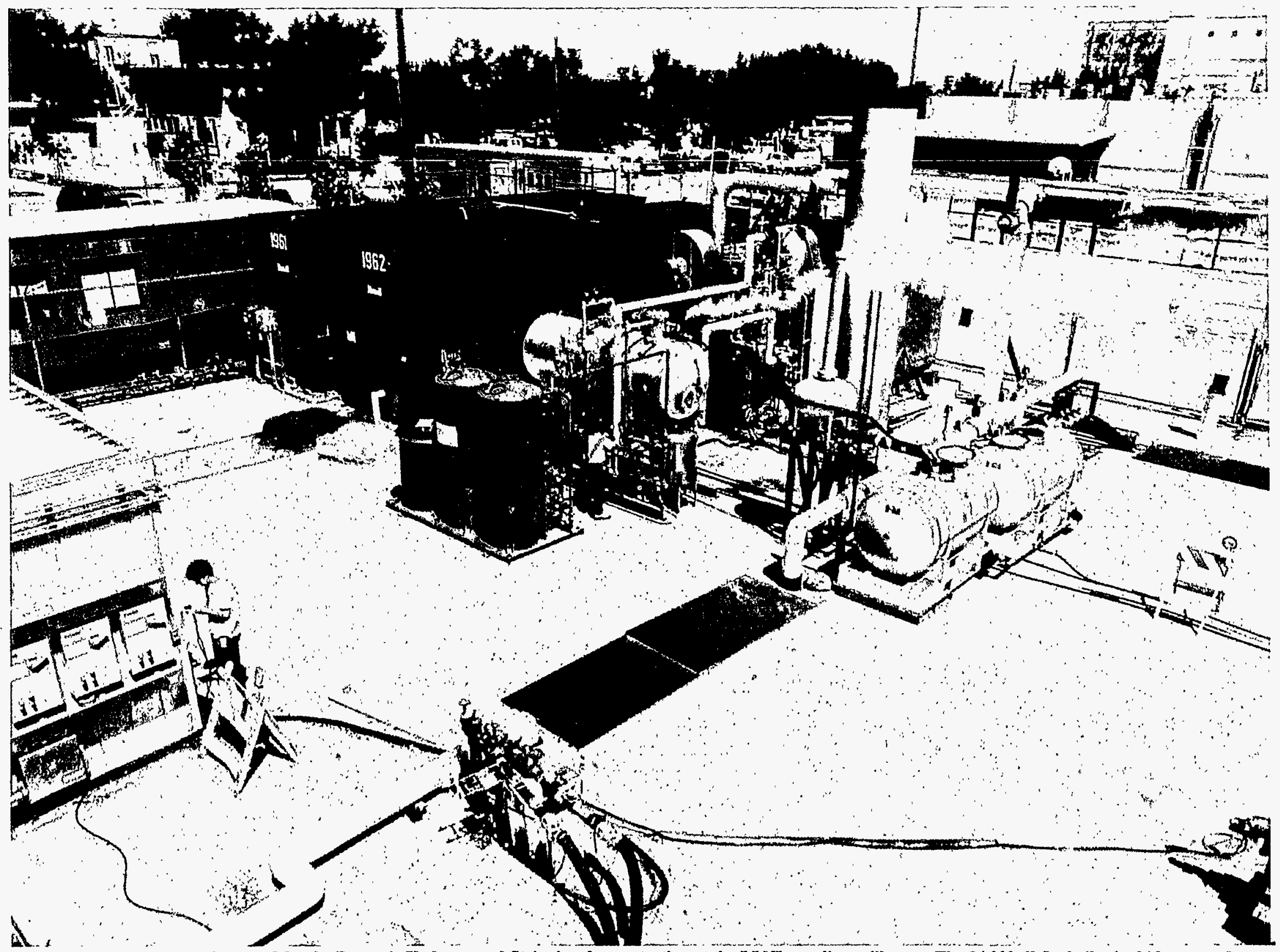

Figure 9. Portable steam plant used for the Dynamic Underground Stripping demonstration at the LLNL gasoline spill area. The $24,000-1 \mathrm{~b} / \mathrm{hr}$ boiler is skid-mounted; this particular unit was leased by the month. A steam injection/electrical heating well can be seen in the foreground. Steam is distributed to the injection wells via nexible rubber hoses. The boiler is fired by natural gas and fed by Laboratory drinking water, both from Laboratory utility lines. An injection well is seen in the foreground, with two injection lines (one for each steam zone). Steam is piped to the wells using fexible reinforced-rubber steam lines. 


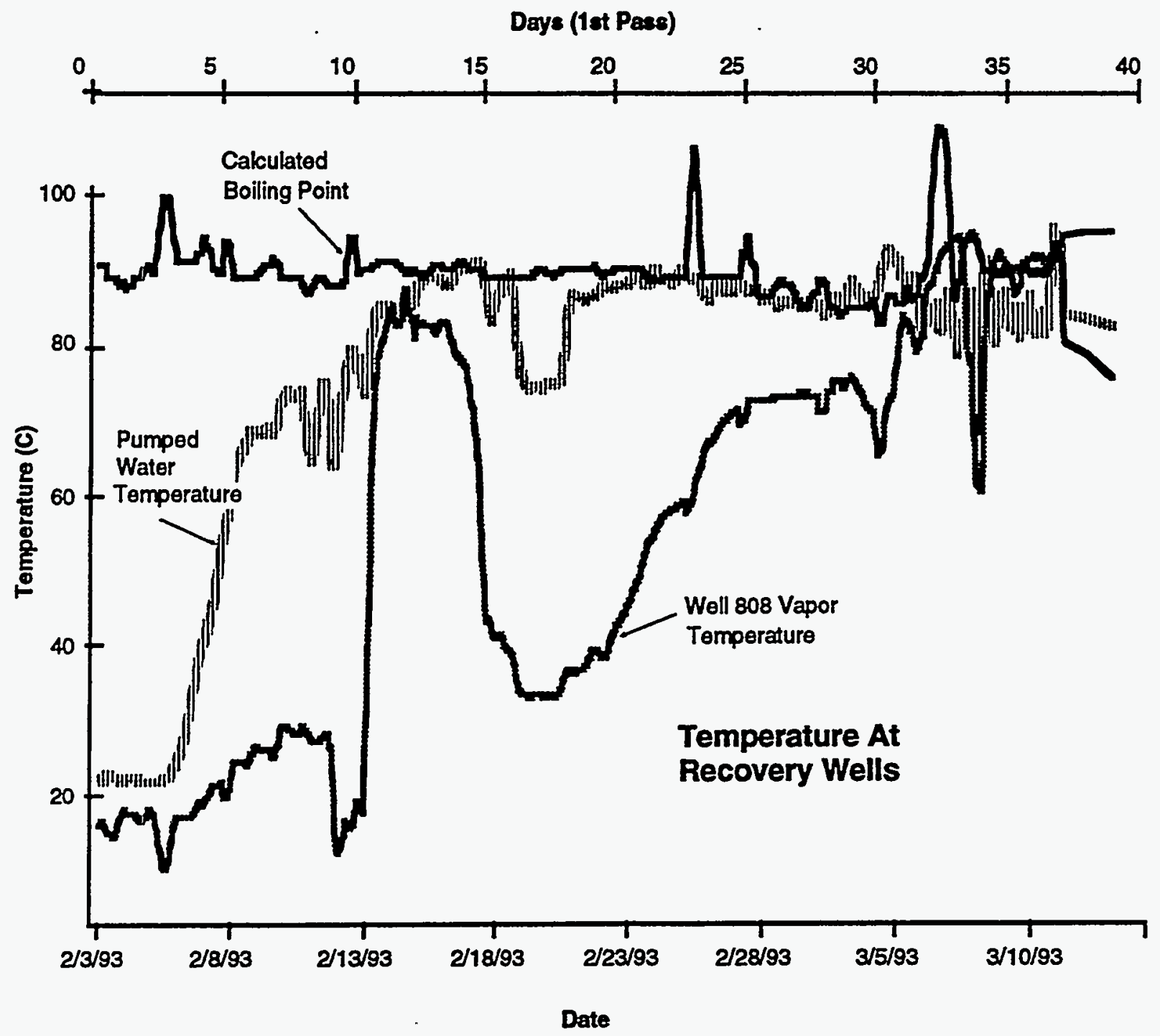

Figure 10. Extraction well temperatures during the first steam pass. Steam breakthrough to the extraction wells occurred about 12 days after steam injection began in the lower steam zone. Calculated boiling point based on the vacuum applied to the well. (After Aines et al., 1994).

continuous temperature loggers showed a rapid temperature rise in the more permeable zones (Figures 6 and 12). The temperature logs revealed thermal gradients of up to $100^{\circ} \mathrm{C}$ over just a few feet depth during initial steam injection, and provided the most accurate measurements of the vertical distribution of the steam at the 11 locations (Newmark, 1994b; Kenneally, 1994).

Between the wells, ERT proved to be a rapid and accurate way to map steam progress at $1-2-m$ resolution, providing actual images of the heated zones by comparing the electrical resistance distribution before heating to that afterwards.
(Ramirez et al., 1994) (Figure 13). Daily ERT images showed the vertical extent of the steam zones and the lateral movement between imaging wells. They revealed a number of areas where steam was moving vertically in the formation that were not detected by the temperature logs in individual wells. The total cycle time to obtain and process the data for each image was about an hour. This made ERT the principal control method, and decisions on steam injection rates made at the morning operations meetings were based principally on ERT images from the previous day. Coupled with the temperature profiles from the continuous temperature loggers, steam 


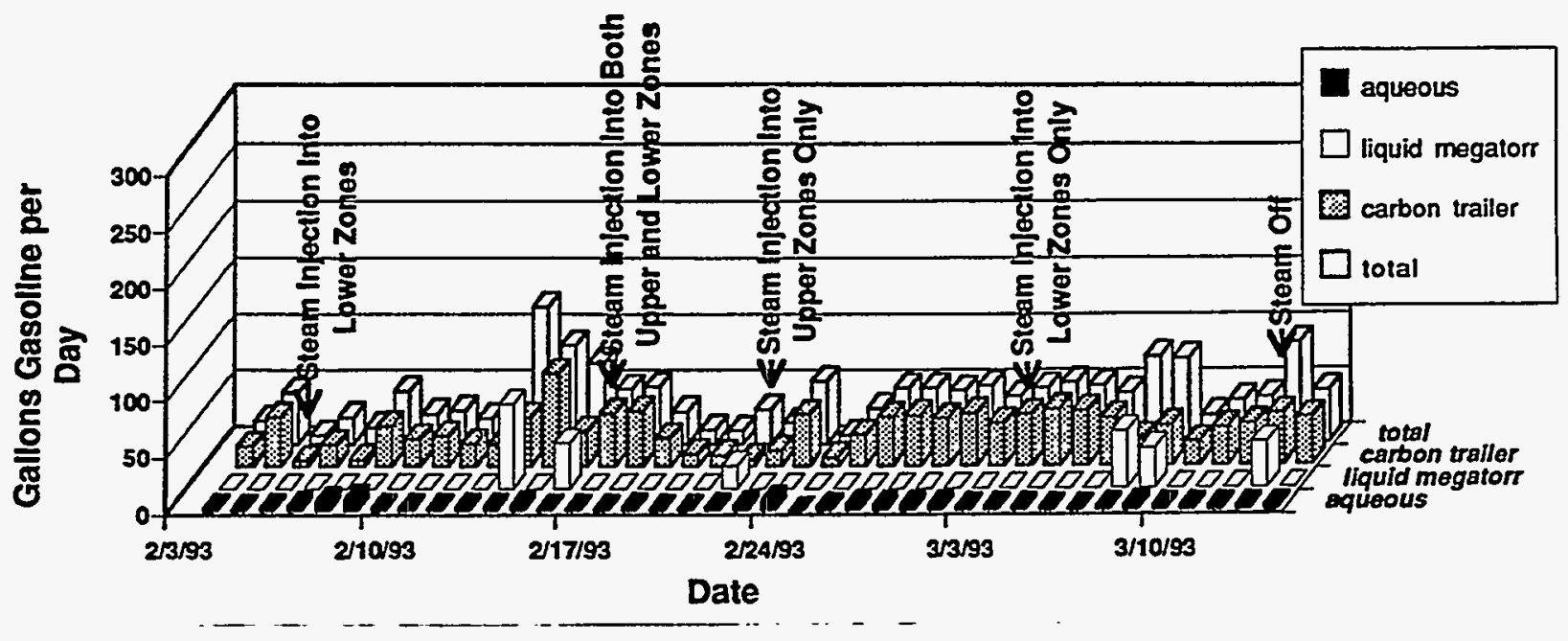

Figure 11. Daily average gasoline recovery rates during the first steam pass. (From Udell, 1994a,c).

progression through the formation was seen to occur in multiple horizontal permeable zones, with significant vertical motion occurring in some areas. The combined ERT/temperature 2-in. fiberglass wells were placed to allow optimal monitoring of the interior of the treated zone (extending about $30 \mathrm{ft}$ outside the ring defined by the steam injection wells) and lower-resolution monitoring of the surrounding area. Induction logs run in the monitoring wells revealed the changes in the electrical properties of the heated soils in detail. These results were used to calculate fluid saturation in the steamed zones (Boyd et al., 1994) (Figure 14).

An array of tiltmeters was installed nearsurface in a double ring surrounding the site to monitor the lateral extent of the steam zone outside the treated area (Hunter and Reinke, 1994). The array was used in two modes: passive and active.

In the passive mode, tiltmeters measure the small deformations in the ground surface that result from a subsurface pressure transient in terms of tilt. As the steam front moving in the subsurface approaches a tiltmeter, it produces a pressure transient and causes the ground to deform. If the signal is sufficiently large, the tiltmeter will detect the slight tilt resulting from that pressure transient. Using this method, we mapped the outer extent of the steamed region during steam injection.

In a more active mode, the tiltmeter array was used to measure the slight deformation in the ground surface resulting from a pressure tran- sient induced into the steam zone by shutting off an injection well for a fixed time. Maps of the areal extent of the steam zone emanating from each well could then be obtained, particularly for the lower steam zone (located below the presteam water table). This technique was extremely effective in mapping the lateral spread of steam and the development of any preferential steam pathways.

During the first steam pass, tiltmeters were primarily relied upon to delineate the outer extent of the steam front. We tested and validated the processing technique whereby the individual steam zones could be mapped during this pass, where the subsurface monitoring network of temperature measurements and ERT image planes could provide ground truth.

The second steam pass was begun after a 3-month hiatus to redesign the effluent treatment capacity, establish better analytical control on the effluent stream based on our new knowledge of the comparative flows in vapor and water, and evaluate the cost-effectiveness of the process. In this pass, we optimized the amount of time the formation was kept under vacuum (no steam injection) and greatly increased the extraction rate, hitting a contaminant recovery peak of more than 250 gallons/day and routinely removing more than 100 gallons/day (Figures 15 and 3).

The focus of the various monitoring activities was somewhat different during this pass, where steam was being injected into previously heated soil. Although the ERT images continued to provide valuable information, interpretation was 

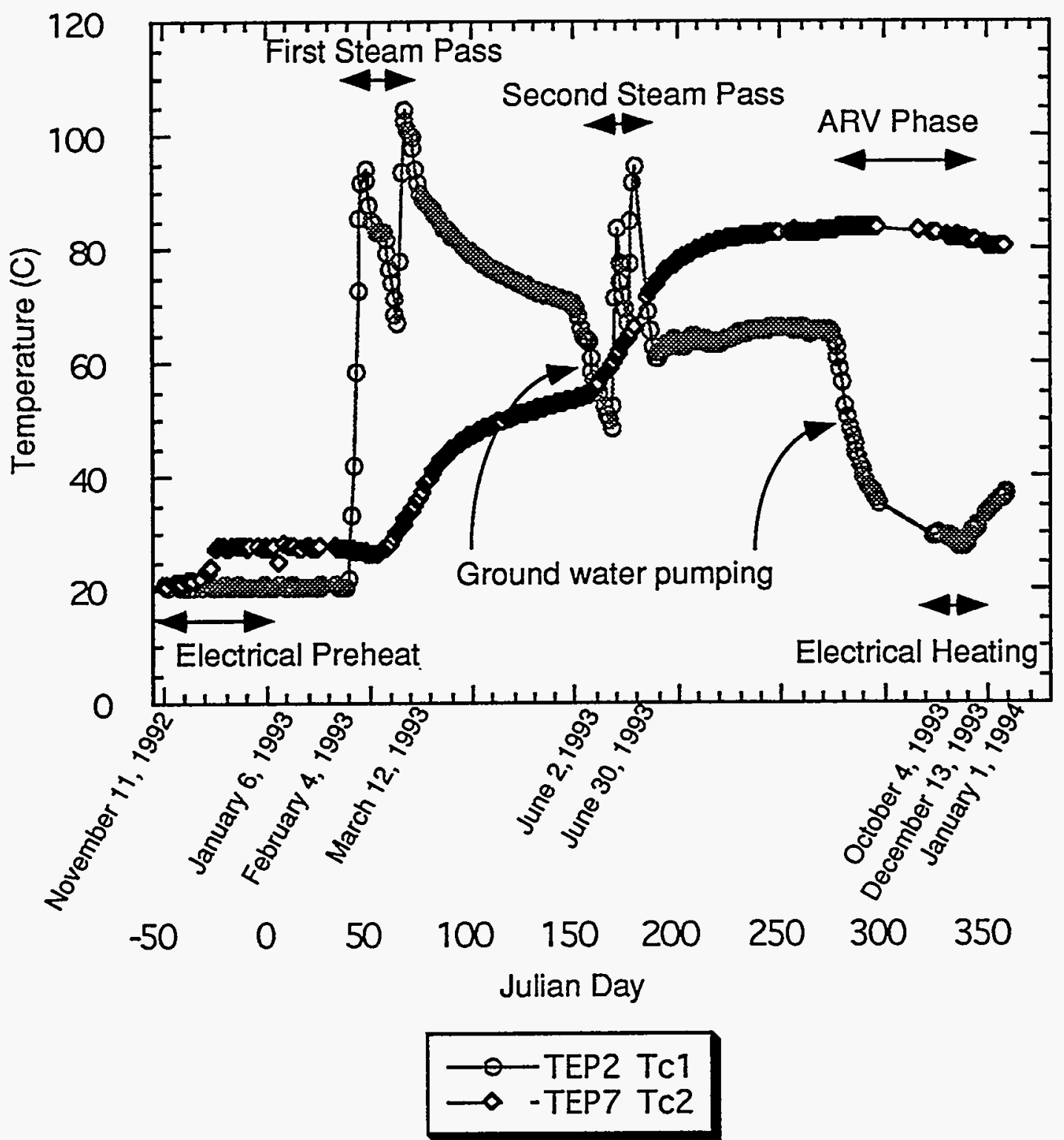

Figure 12. Individual thermocouples reveal the thermal history of different soil types at fixed locations in the field. A temperature record of a thermocouple positioned at about $40-\mathrm{m}$ depth in a permeable gravel unit in the lower steam zone in well TEP 2 shows rapid temperature increases during steam injection. During groundwater pumping, cool fluids are drawn across this location from outside the steamed area, causing temperatures to decrease. By contrast, a thermocouple positioned at about 34-m depth in a clayrich unit in well TEP 7 shows gradual temperature increases resulting from electrical heating and steam injection. Both fixed thermocouples lie below the standing water table. (After Newmark, 1994b).

more difficult, as the contrast between steam and hot soil was diminished by nearly an order of magnitude. Temperature measurements were similarly more difficult to interpret, as the relative temperature changes in the treatment area grew smaller.

The tiltmeter array was used to determine the horizontal dimensions of the steam zone, and we relied more heavily on the tiltmeter maps of individual steam zones (Figure 16). This was particularly important during the second steam pass, when steam was alternately injected into selected wells to target the remaining cooler zones. Using the tiltmeter maps and temperature logs for guidance, we injected steam into two or three wells at a time to selectively heat portions of the pattern 

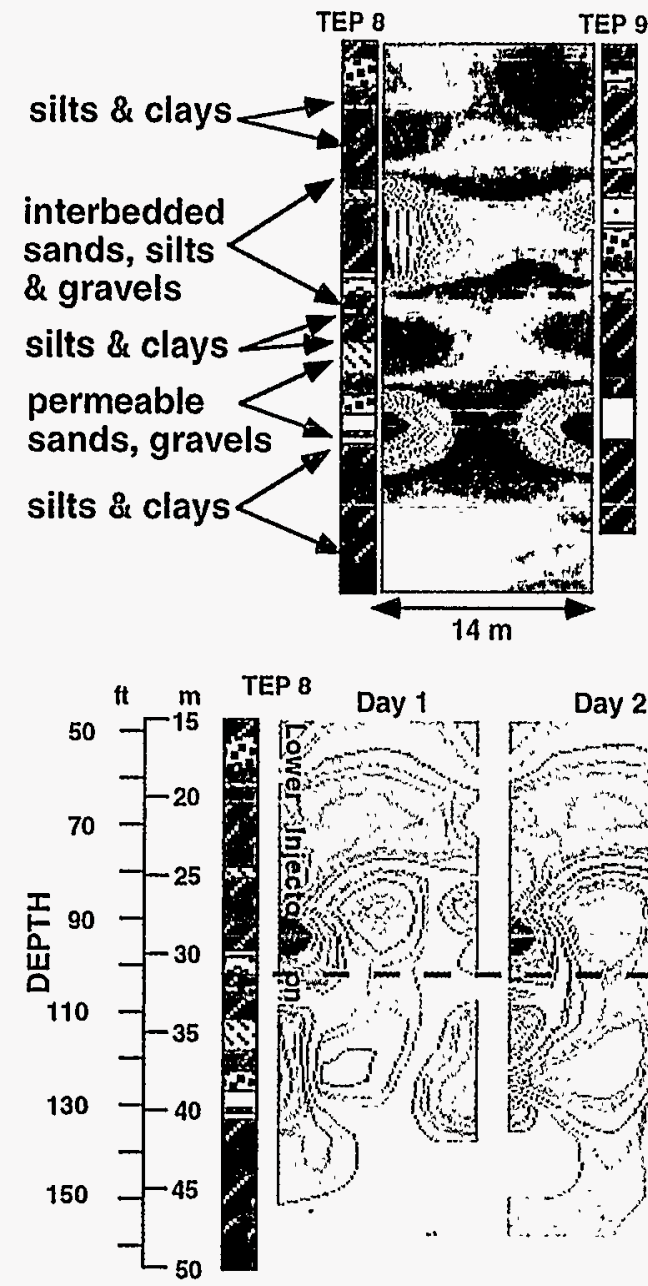

Day 2
-Water

table

\section{Absolute Image}

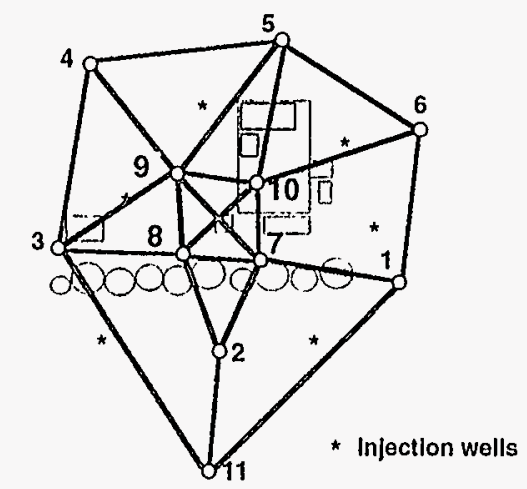

Resistivity ( $\log$ ohm m)

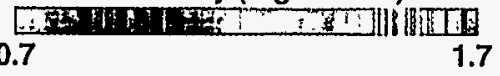
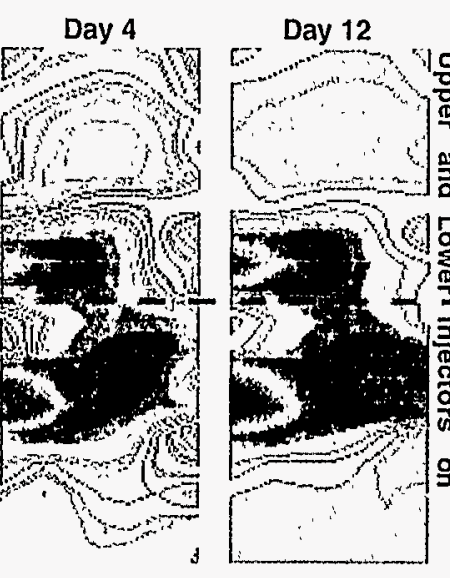

Day 16

Day 36

TEP 9
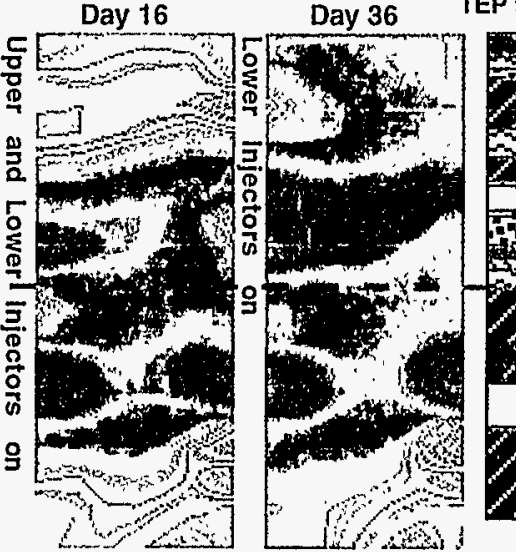

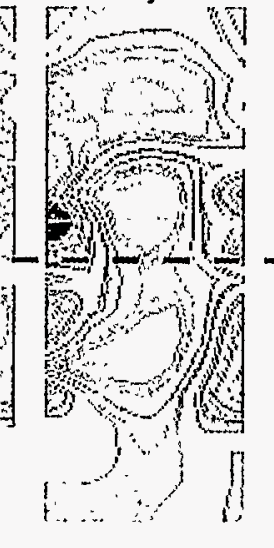

Resistivity change (ohm $\mathrm{m}$ )

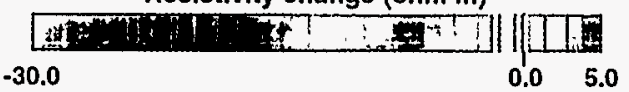

Figure 13. Electrical Resistance Tomography (ERT) images. Top: ERT absolute images reveal the continuity of soil units across image planes. The resistive units correspond to the more permeable sand and gravel zones; the conductive units correspond to the clay-rich intervals. (The apparent pinching-out of units in the center of the image is due to the increase in resolution radius toward the center of each image). Bottom: ERT difference images show the progress of the steam fronts across the image plane, starting from the first day of steam injection. This image plane (between wels TEP 8 and TEP 9) is located approximately $6 \mathrm{~m}$ from the nearest injection well, and is oriented nearly perpendicular to a line linking it and the extraction wells. Small decreases in electrical resistivity are observed within hours of the start of steam injection. Although steam was initially injected into only the lower steam zone (centered at about 35-m depth), steam leaked into the upper steam zone (centered at about $25-\mathrm{m}$ depth) through the well completion in the nearby injection well; this is evidenced by the resistivity decreases in both zones in these images. By the end of the first steam pass (Day 36), both the upper and lower steam zones were at or near steam temperature, with conductive heating occurring in the neighboring clay-rich units. The preferential steam paths closely follow the more resistive units seen in the absolute images. (From Newmark, 1994b). 


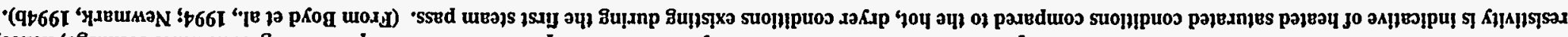

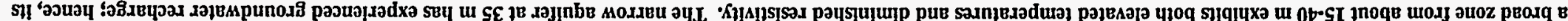

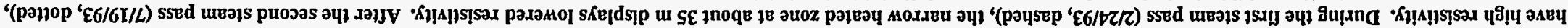

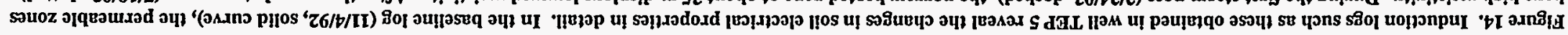

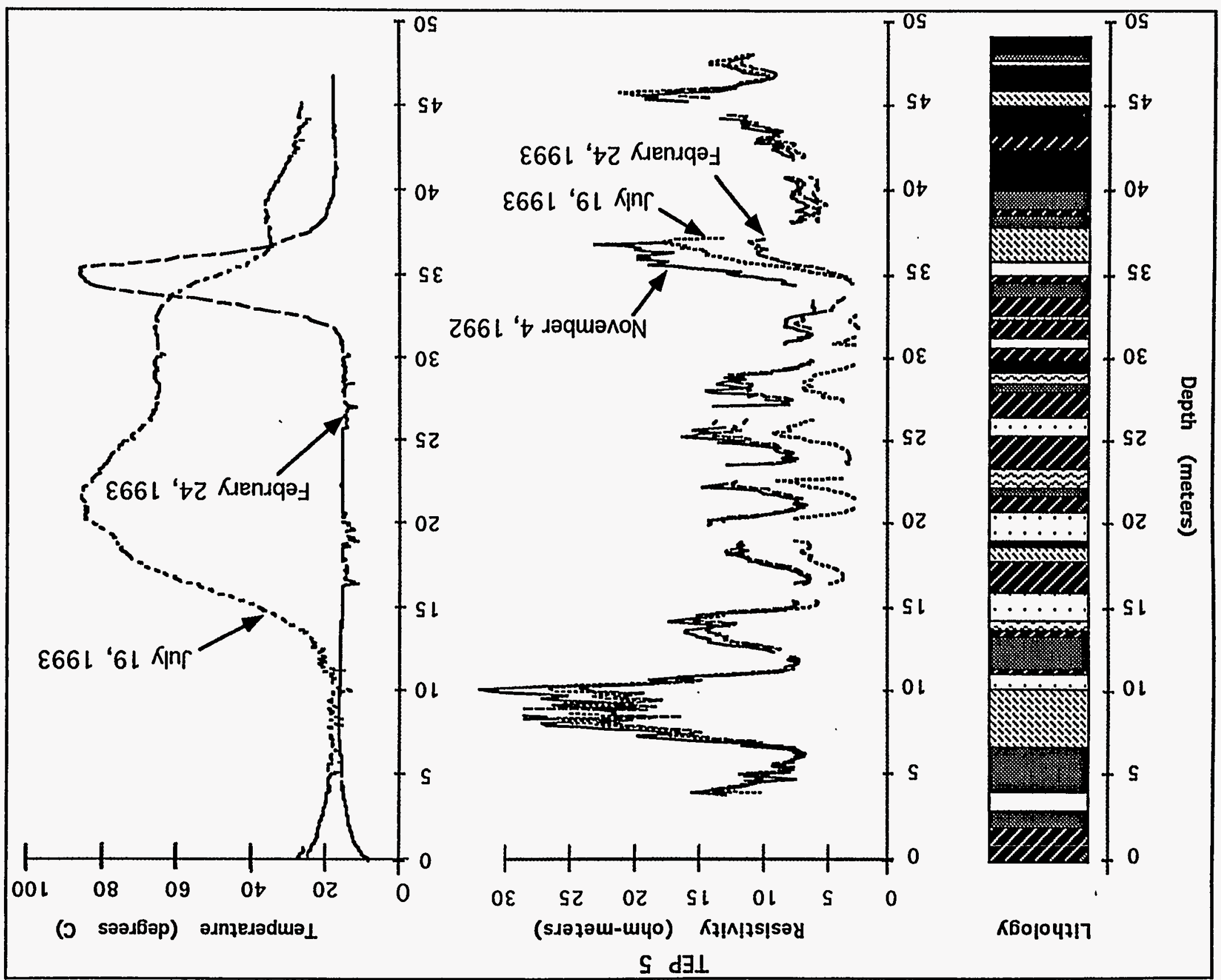




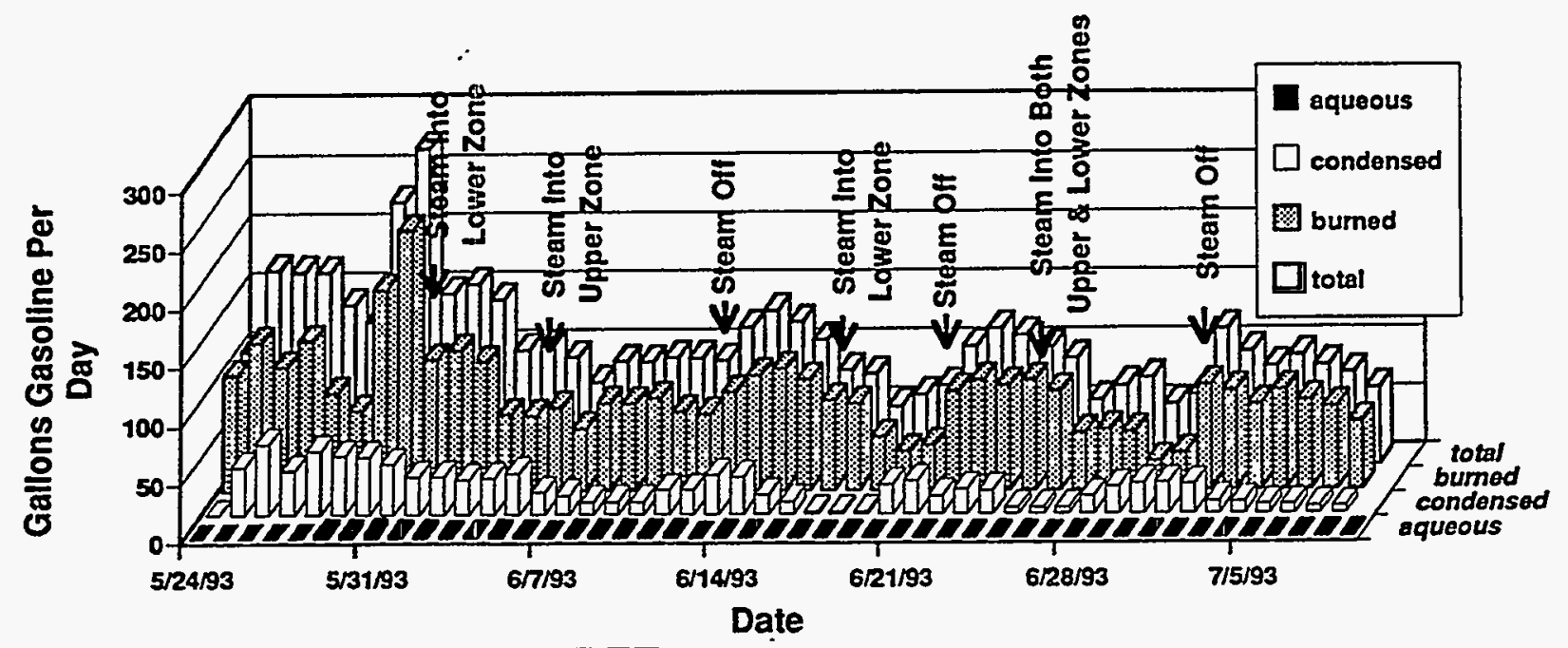

Figure 15. Daily average gasoline recovery rates during the second steam pass. (From Udell, 1994a,c).

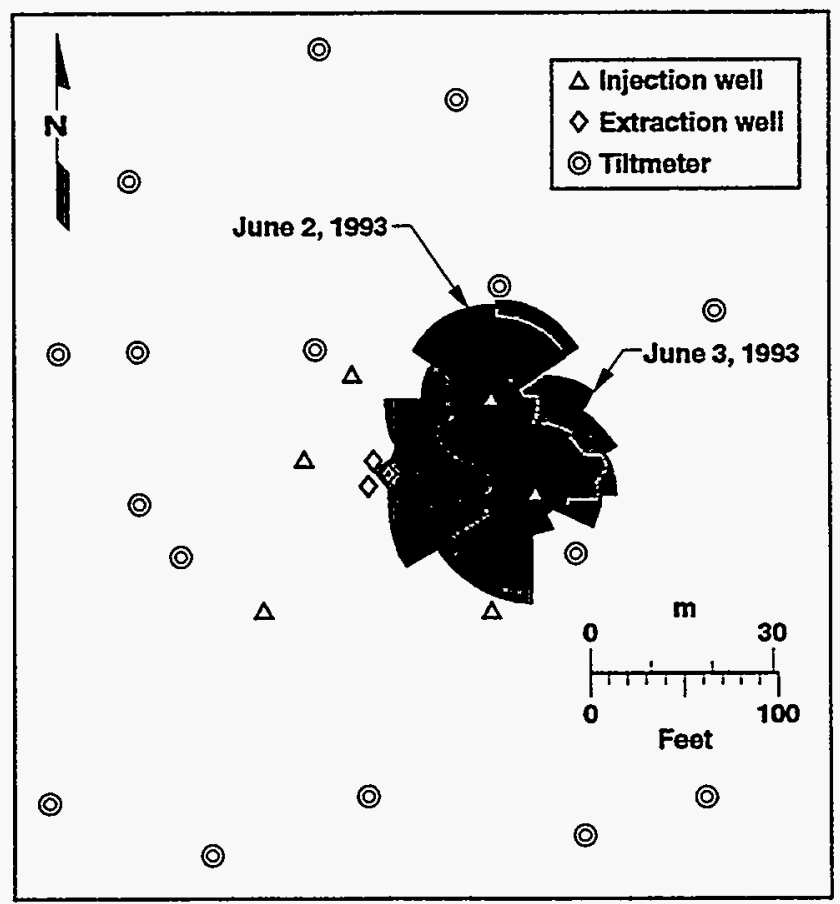

Figure 16. Tiltmeter maps show the growth of the team fronts emanating from two injections wells on consecutive days. At this time, steam was being injected into only two wells, below the water table. Steam broke through to the extraction wells the third day. (From Hunter and Reinke, 1994). 
and "sweep" the steam across the remaining cool areas. The pulsed mode of operation, alternating steam and vacuum-only on a 5-6-day cycle, was very effective at maximizing contaminant removal. We terminated this phase on schedule on July 9,1993 , while the extraction rates still ranged between 50 and 100 gallons/day.

Evaluation of the gasoline concentration in the effluent from the extraction well proved difficult in the first pass, but was significantly improved in the second pass (Jovanovich et al., 1994; Aines et al., 1994). Most of the gasoline was removed in the vapor phase, and much of that was condensed along with a large amount of water in the heat exchanger (Aines et al., 1994). The second-pass addition of an oil-water separator on this part of the effluent stream allowed an accurate determination of the condensed part of the flux by simple volume measurement (Sorensen and Siegel, 1994). The remaining dried, cooled vapor was burned in two internal combustion engines; the flux of gasoline in this stream was highly variable, as a function of the amount of steam in the injection wells, total vacuum applied, and time of day (temperature of the heat exchanger).

Because of the cost and hazards associated with sampling and analysis, off-line vapor samples were collected only once or twice daily. This sampling frequency provides somewhat limited insight into the Dynamic Underground Stripping process, and cannot provide sufficient data for detecting short-term fluctuations in system performance or for real-time optimization and control of the system.

We employed a series of continuous in-line chemical sensing systems to measure this flux and to allow the same level of control for the chemical extraction rate as was obtained for the thermal injection systems. These included a standard Fourier-transform-infrared (FT-IR) spectrometer equipped with a gas sample cell, an automated gas chromatograph (with photoionization detector), and the experimental Differential Ultraviolet Absorption Spectroscopy (DUVAS) system. The trends indicated by the in-line sensors were in agreement with standard off-line laboratory analyses, and were obtained continuously in near or real-time (Figure 17a).

Continuous monitoring allowed transient events and mid- to long-term trends in the extraction process to be measured. For example, the DUVAS data showed significant diurnal fluctuations in the absorption of total aromatic compounds; these fluctuations corresponded with recorded variations in ambient temperature and changes in the pressure and flow rates within the vapor extraction system (Barber et al., 1994a,b) (Figure 17b). The correlation between ambient temperature and sensor response led to an analysis of the vapor system's efficiency. The fluctuations appear to be caused by changes in condensation efficiency resulting from variations in ambient temperatures (higher condensation rates during the cooler nighttime temperatures.) This explanation also resolved the apparent scatter between the contaminant concentrations measured in the morning and afternoon vapor samples. (The morning values showed significantly lower concentrations than the afternoon samples.) Thus, the in-line sensors, due to their high sample frequency, revealed trends that occurred between samples and provided a context in which to interpret the analytical results.

During the second steam pass, about 5000 gallons of gasoline were recovered. Extraction rates were extraordinarily high at the beginning of the second pass because of the 3-month heat soak of the formation and the accompanying release and volatilization of gasoline (Aines et al., 1994).

By the end of the two steam injection phases, most of the soil within the treatment volume was heated to the boiling point of water. Only the thick clay layer at 95 to $110 \mathrm{ft}$ in depth did not reach this value, in places reaching only $80^{\circ} \mathrm{C}$. It was within this "cold spot" that the largest concentrations of gasoline remained (Figure 18).

Drill-back characterization utilizing six boreholes in a line across the spill site after these first two phases indicated that, as expected, there was still free-product gasoline in the vicinity of the extraction wells but that it was now restricted to a small area just below the water table (Figure 19). Based on the observed soil concentrations, it was estimated that about 750 gallons remained in the clay unit. Gasoline had been substantially removed from the edges of the spill and from the vadose zone.

Of significant importance to this experimental application of Dynamic Underground Stripping was the finding that gasoline concentrations were not increased in the soil outside the treatment volume. However, groundwater and vapor gasoline concentrations were still very high.

At this point, operational control of cleanup activities at the gasoline spill site was transferred 

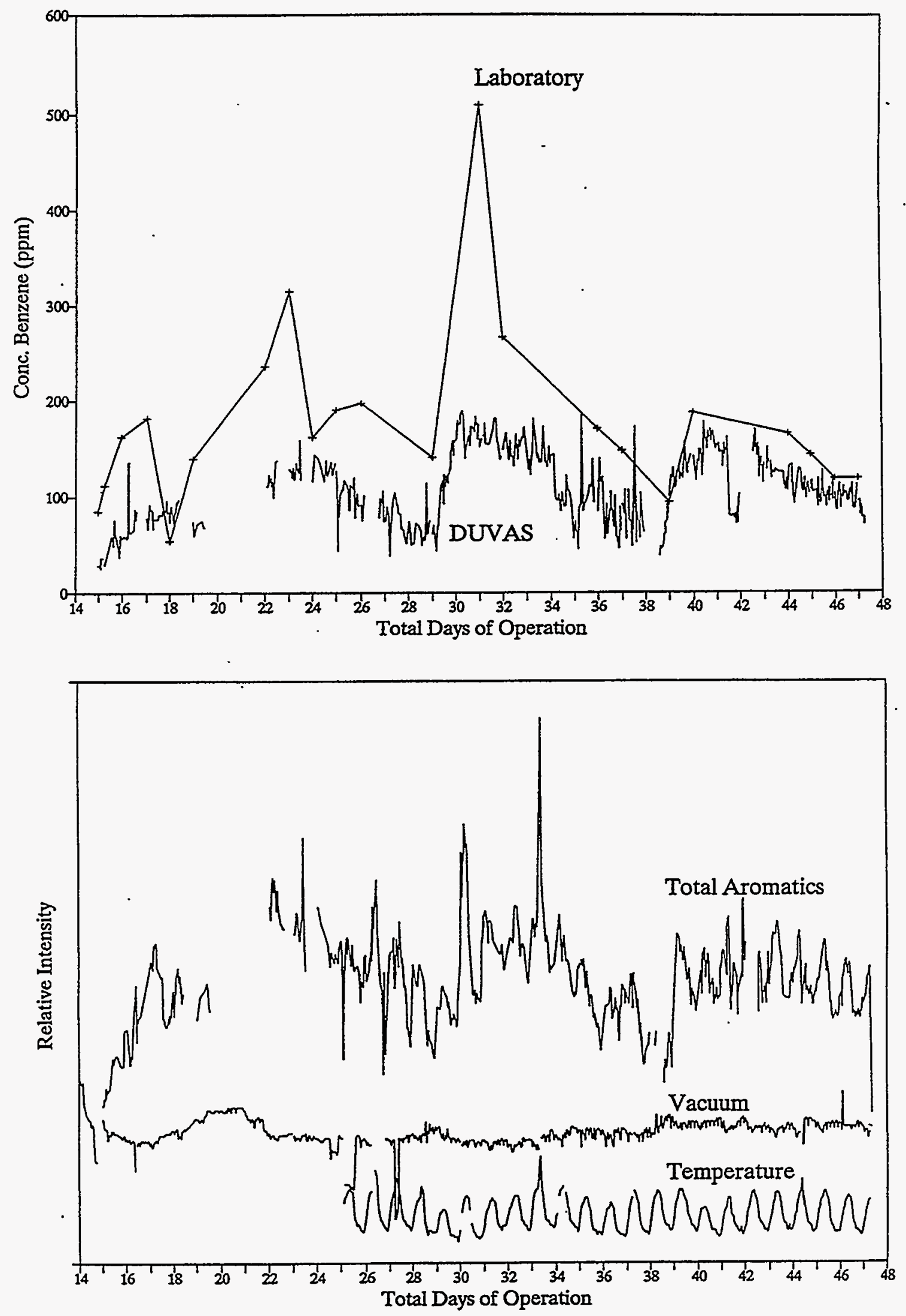

Figure 17. (a) Comparison of the benzene concentration measured by DUVAS and off-line laboratory analyses, (b) Observed variations of relative total aromatic concentration from DUVAS, extraction line vacuum, and vapor temperature. (From Barber et al., 1994a). 


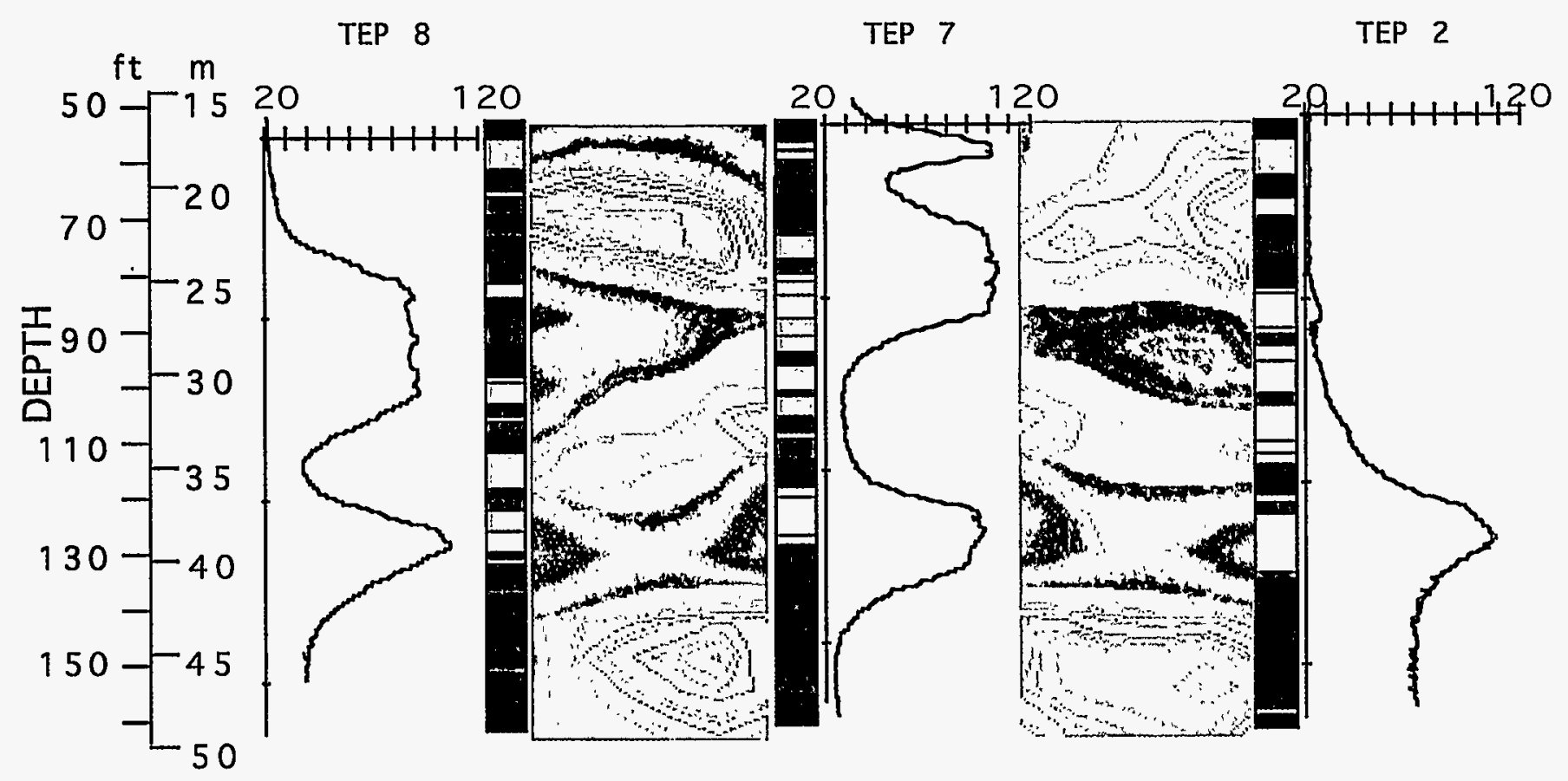

Data for $3 / 11 / 93$, end of first steam pass

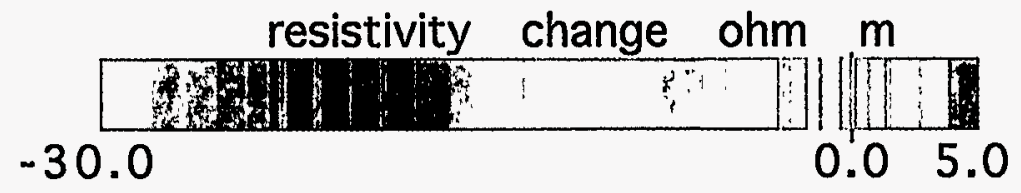

Figure 18. ERT and temperature surveys detected a "cold spot" after the first steam pass. Data from March 11, 1993, at the end of the first steam pass, reveal a zone between about $32 \mathrm{~m}$ and $37 \mathrm{~m}$ where temperatures have not risen much above ambient. The ERT images indicate the lateral continuity of this zone between wells in which temperatures can be measured. 


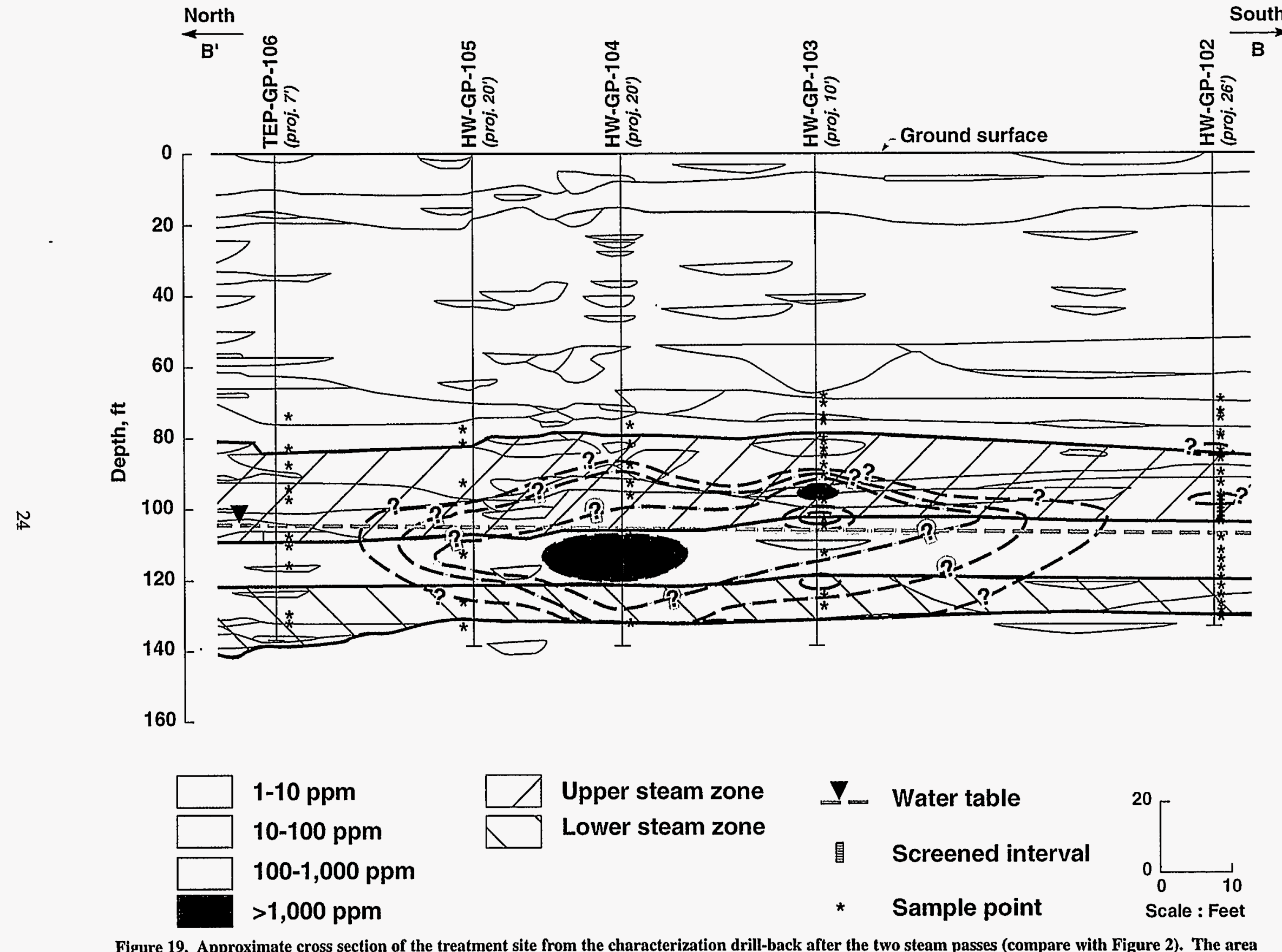

Figure 19. Approximate cross section of the treatment site from the characterization drill-back after the two steam passes (compare with Figure 2). The area of gasoline contamination has contracted greatly, and there are no indications of free product remaining in the treated area outside the volume immediately around the extraction wells. No gasoline has been dispersed outside the treated volume. (From Bishop et al., 1994). 
from the more experimental Dynamic Underground Stripping demonstration team to the LLNL site cleanup organization. Subsequent activities focused on the final cleanup of the site.

Extraction of groundwater and vapor resumed as part of the Accelerated Recovery and Validation (ARV) project (Sweeney et al., 1994) in October 1993; the spike in initial extraction rates was smaller than observed after the first pass (Figures 20 and 3). Electric heating was applied to the system in November. Approximately 1000 gallons were removed during this phase, with the concentrations and extraction rates falling dra- . matically. Electric heating raised the overall temperature of the treated zone only slightly, apparently because the extraction systems were removing large amounts of heat ( 50 to $100 \mathrm{~kW}$ ) at the high temperatures prevailing at the time.

When the extraction systems were turned off, temperatures in the clay zones began rising (Figure 21). The electric heating was terminated on December 16, and the system was shut down for the holidays. At this point, at least 7600 gallons of gasoline had been removed from the site. The discrepancy between this and the 6200 gallons estimated to be present is not surprising due to the extreme heterogeneity of the site and the difficulty in characterizing gasoline trapped in soil capillaries. Historically, very few measurements of total hydrocarbons were made at the site, since measurements of BTEX (benzene, toluene, ethylbenzene, and xylenes) were sufficient to delineate the contamination and quantify . the regulated contaminants (Dresen et al., 1986). The error in converting the BTEX measurements to total gasoline is therefore fairly large, and the estimated total volume of gasoline subject to an error of several thousand gallons (Devaney, 1994; Aines et al., 1994).

In January 1994, groundwater pumping and vapor extraction resumed. During the 1-month shutdown during the 1993-1994 year-end-break, concentrations in the vapor increased only slightly, and water concentrations decreased. Benzene concentrations in the extraction wells continued their downward trend, now at less than $200 \mathrm{ppb}$ from a peak of $7000 \mathrm{ppb}$ before the start of steam injection. At a groundwater monitoring well within the pattern, benzene concentrations have decreased dramatically, from several thousand parts per billion before Dynamic Underground Stripping to less than $30 \mathrm{ppb}$ in January 1994. Other wells show similar decreases. These factors indicate that there is no significant free-phase gasoline remaining in the treatment volume, although significant contamination may still lie outside the treatment volume.

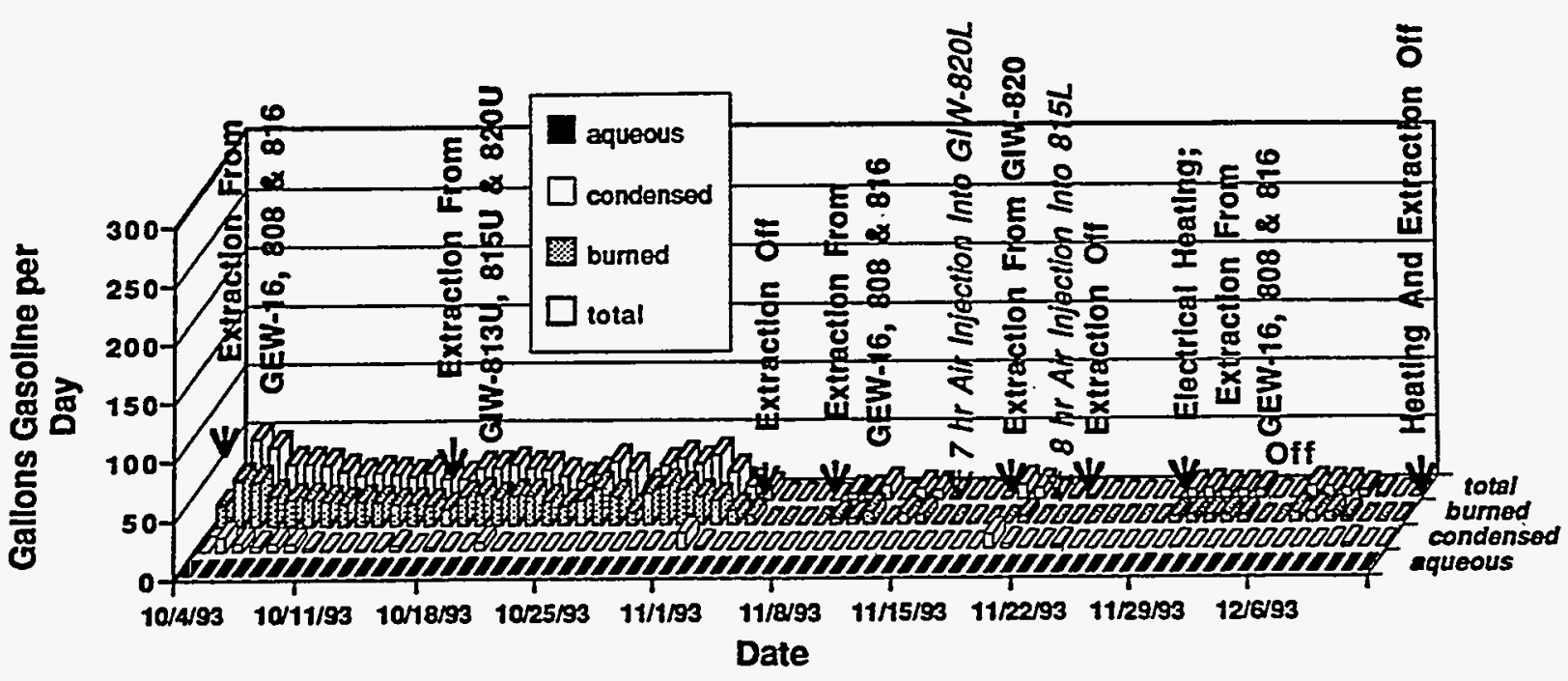

Figure 20. Daily average gasoline recovery rates during the ARV phase. (From Udell, 1994a,c). 


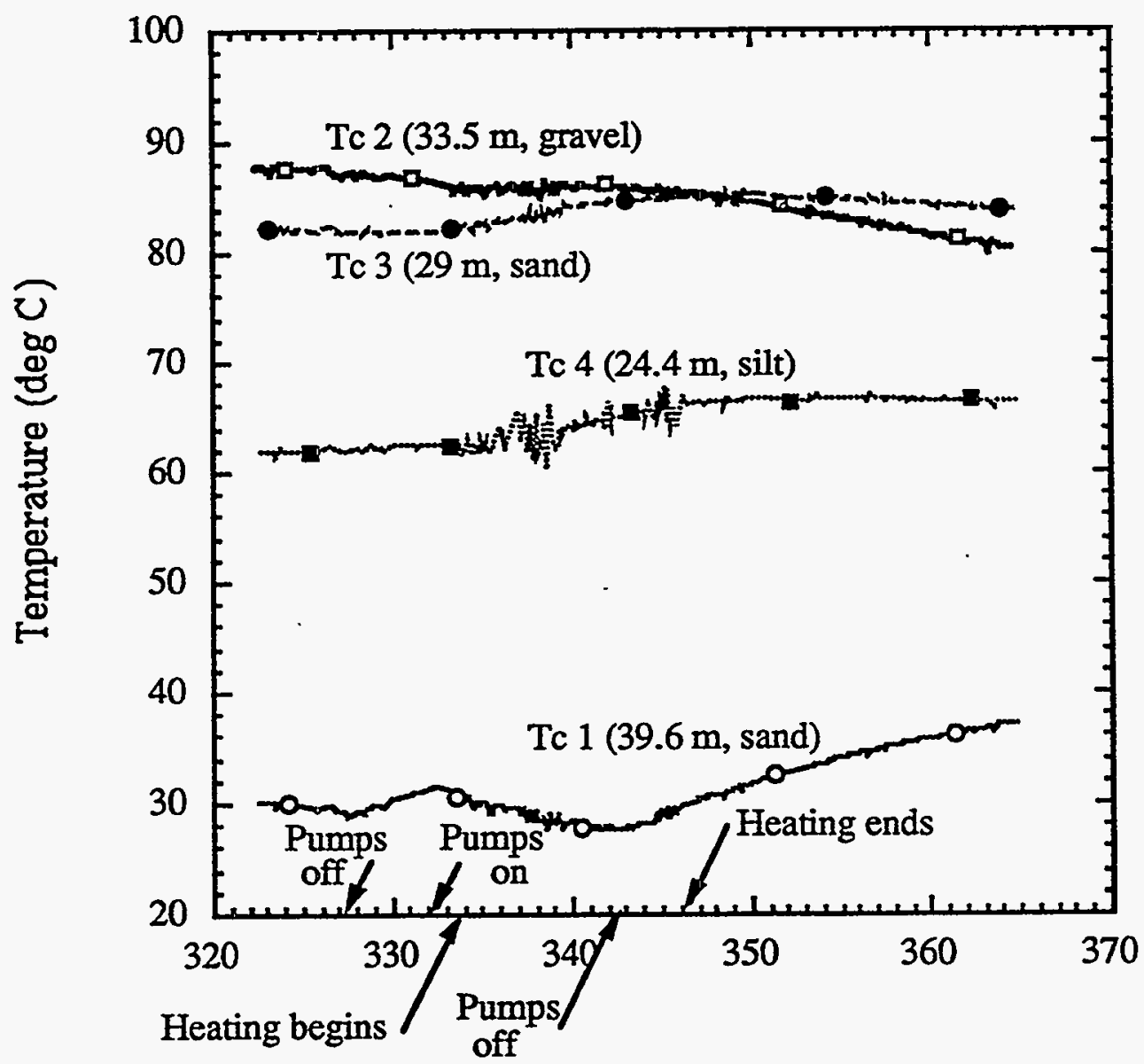

\section{Julian day}

Figure 21. Fixed thermocouples in well TEP 2 show different responses to electrical heating during the ARV phase. Slight temperature rises occur in sandy or silty zones, even while the extraction systems were removing heat from the system. The two lower thermocouples (Tc 1 and 2, open symbols) are located below the standing water table. The two thermocouples above the water table (Tc 3 and 4, closed symbols) show temperature rise throughout electrical heating. (After Sweeney et al., 1994).

\section{Cleanup Results}

\section{Free-Product Removal}

Free-product gasoline has been removed from the treated area at the LINL gasoline spill site, thus accomplishing the goal of Dynamic Underground Stripping; approximately 7600 gallons of gasoline were removed from above and below the water table. This conclusion deserves careful scrutiny because of the previous great difficulty in accomplishing this goal experienced by other cleanup methods.

The bases for this conclusion are:

1. 6200 gallons of gasoline were estimated to be in the treatment zone, and 7600 have been removed. After the August 1993 drill-back, soil concentrations indicated that 750 gallons remained (if the distribution was symmetric). Over 1000 gallons have since been removed. Extraction rates fell to nearly zero (11 gallons per month) in January 1994 and have remained low.

2. Groundwater concentrations in the extraction wells and in the two available monitoring wells inside the pattern (GEW 710 and GSW 1A) are lower than the apparent solubility of the most recently extracted gasoline. Although the solubility of gasoline can vary greatly depending on its composition, by measuring the concentration in the water in the oil-water separator where raw 
gasoline is known to be in contact with groundwater (Jovanovich et al., 1994; Sweeney et al., 1994), an accurate estimate under site conditions can be obtained. The equilibrium concentrations currently are $>35,000 \mathrm{ppb}$ at $20^{\circ} \mathrm{C}$; groundwater samples from the extraction and monitoring wells are less than $10,000 \mathrm{ppb}$ at elevated temperatures $\left(>50^{\circ} \mathrm{C}\right)$. These are well below the initially observed values for water in contact with free product when wells were drilled $(40,000-70,000$ $\mathrm{ppb})$, and an order of magnitude below the values observed in the monitoring wells after electrical heating mobilized gasoline $(120,000-$ $180,0000 \mathrm{ppb}$ ).

3. Vapor and liquid concentrations did not rise significantly after the December 1993-January 1994 shutdown period. Previous shutdowns with hot ground resulted in large increases in concentration when the treatment system was turned on again. Presumably, this was due to the mobilization and/or vaporization of free-product gasoline. The absence of such a pulse after ARV indicates that there was no free product remaining.

4. Groundwater concentrations of BTEX at the central extractors are at lower values than the initial groundwater concentrations just outside the injection ring (e.g., GSW 2, 3, 13), and are at comparable concentrations to many of the distal wells (see below).

The limitations to the conclusion that we have removed all the free product are:

1. Our ability to resolve the presence of freeproduct pockets by chemical means is limited by the degree of contact with flowing air or water. This is difficult to quantify.

At the start of ARV, the remaining gasoline left a chemical signature of $20,000 \mathrm{ppb}$ total petroleum hydrocarbons (TPH) in groundwater, which dropped to $10,000 \mathrm{ppb}$ by the end of the ARV phase (Sweeney et al., 1994). During ARV, about 1000 gallons of gasoline were removed. This places an upper limit on the free product remaining in the treated area today, based on groundwater analysis alone of 1000 gallons.

There are approximately 1 million gallons of groundwater in the near vicinity of the extraction wells. Given the observed concentrations of TPH during the ARV phase, this places a lower limit of 10-20 gallons (dissolved in groundwater). This indicates that there are much less than 1000, but possibly on the order of tens, of gallons of gasoline remaining ( $99.9 \%$ removal would correspond to about 10 gallons remaining). Any pocket of free product near the extraction wells would have to be extremely well isolated from the permeable parts of the formation to have survived.

2. Free product may remain in the area outside and east of the treated area (e.g., near GSW 216). The vapor concentrations in the easternmost injection well (GIW 815) are still fairly high (Sweeney et al., 1994). This may be due to either free product in the area or from the vapor being pulled in from the area to the east. It is more likely that this results from vapor being pulled in from the east; if there were free products in the area, we would have seen this in the GSW-001A results. In addition, there was a pocket of free product under the receiving yard to the north of the treatment area before Dynamic Underground Stripping was begun. This was sampled during the drilling of TEP 5 (Bishop et al., 1994).

\section{Groundwater Cleanup}

Cleanup of groundwater is the goal of any remediation effort, so the results of the LLNL demonstration must be measured principally in terms of the resulting contaminant concentrations in the water beneath the site even though the goals of the project were strictly limited to free-. product removal. The regulated contaminants 1,2 dichloroethane (DCA), xylene, and toluene are at or near their allowed Maximum Contaminant Limit (MCL) in the groundwater of the treated area. Benzene has been reduced dramatically, although it is still well above the MCL (Table 2, Figure 22).

Table 2 gives average values for the major regulated contaminants in the central region of the gas pad; this requires the use of data from several wells, as noted. Dynamic Underground Stripping went far beyond free-product removal; it lowered the benzene concentrations inside the central region to levels below those observed outside the treated area (the so-called bathtub ring of untreated but slightly contaminated water)

(Figure 23).

Concentrations of 1,2 DCA have dropped to below detection limits in the treated area, and are significantly reduced in the surrounding region.

Xylene concentrations are diminished in the treated area. The increase in xylene concentration in GSW 216 (east of the treated area) probably reflects the local mobilization of gasoline components through increased solubility and decreased sorption due to heating (Figure 8). 
Table 2. Average level of contaminant in central extractors.

\begin{tabular}{|c|c|c|c|c|c|c|c|c|c|c|}
\hline \multirow[t]{2}{*}{ Date } & \multicolumn{2}{|c|}{ Benzone 1.0 ppb } & \multicolumn{2}{|c|}{ Toluene $100 \mathrm{ppb}$} & \multicolumn{2}{|c|}{ Xylenes (1750 ppb) } & \multicolumn{2}{|c|}{$1,2 \mathrm{DCA}(1.0 \mathrm{ppb})$} & \multicolumn{2}{|c|}{ Ethylbenzene (680 ppb) } \\
\hline & $\mathrm{ppb}$ & ratio to $\mathrm{mcl}-1$ & $\mathrm{ppb}$ & ratlo to $\mathrm{mcl}-1$ & $\mathrm{ppb}$ & ratho to ma-1 & ppb & ratio to ma-1 & $\mathrm{ppb}$ & ratio to mct-1 \\
\hline 1907 & 6400 & 6399 & 4900 & 48.0 & 2800 & 0.6 & 200 & 399 & 360 & -0.5 \\
\hline 1008 & 4600 & 4599 & 4220 & 41.2 & 2940 & 0.7 & 118 & 236 & 380 & -0.5 \\
\hline 1000 & 1705 & 1704 & 1500 & 14.0 & 1643 & -0.1 & 188 & 375 & 305 & -0.6 \\
\hline 1902 (Pre-DU8) & 3646 & 3645 & 2187 & 20.9 & 2935 & 0.7 & 117 & 233 & 838 & 0.2 \\
\hline 1008 (Average DU8) & 2081 & 2080 & 4143 & 40.4 & 3810 & 1.2 & 0 & -1 & 684 & 0.0 \\
\hline 12/93 (Post-DU8) & 286 & 285 & 804 & 7.0 & 1725 & 0.0 & 0 & -1 & 88 & -0.9 \\
\hline $1 / 04$ & 170 & 169 & 683 & 5.8 & 1866 & 0.1 & 0 & -1 & 36 & -0.9 \\
\hline and & 126 & 124 & 150 & 0.5 & 848 & -0.5 & 0 & -1 & 7.7 & -1.0 \\
\hline opes & 172 & 171 & 177 & 0.8 & 530 & -0.7 & 0 & -1 & 2 & -1.0 \\
\hline enrreos & 200 & 208 & 189 & 0.9 & 448 & -0.7 & 0 & -1 & 6 & -1.0 \\
\hline $\begin{array}{l}\text { Averege of welle } \\
\text { outblds treated area }\end{array}$ & $92 \bullet^{385}$ & 384 & 3 & -1.0 & 6 & -1.0 & 72 & 143 & 5 & -1.0 \\
\hline
\end{tabular}

*Notes: 1987 GSW 15 value from $12 / 15 / 87$

1988 average of values from GSW-015 in 1988

1990 average of tests of GSW $1611 / 6-12 / 14 / 90$

Dala for GSW 001A for DCA only, 1990

1992 Average of GEW 816 tests, aboux 8/15/92

1993 Averuge of all values observed at SEPI part during second pass operations (from Jovanovich et al., 1994)

12193 LLNL Lab dath sampled 12/6/93 , G0-018. UVI part (although SEPI is consistently about 20\% higher)

1/94 Data from LLNL ERD GM-071 sampled 1/19/94, data from UVI port (uncorrected for SEPI/UVI differences if any)

3/94 LLNL lab data G0.091 samplad 3/10/94, UVI part

6/94 LLNL date GP.037 sampled 6/14/94, UVI port. After abour 1 month of toul shue down.

8/94 LLNL ditn GP-096 sampled 8/1/94, UVI port.

LLNL data GP-125 sampled 9/1/94, UVI port.

Outside wells: Average of 1992 values for GSW 8,10,208,216 (wells well outside the treated area that had gasoline contaminant) 

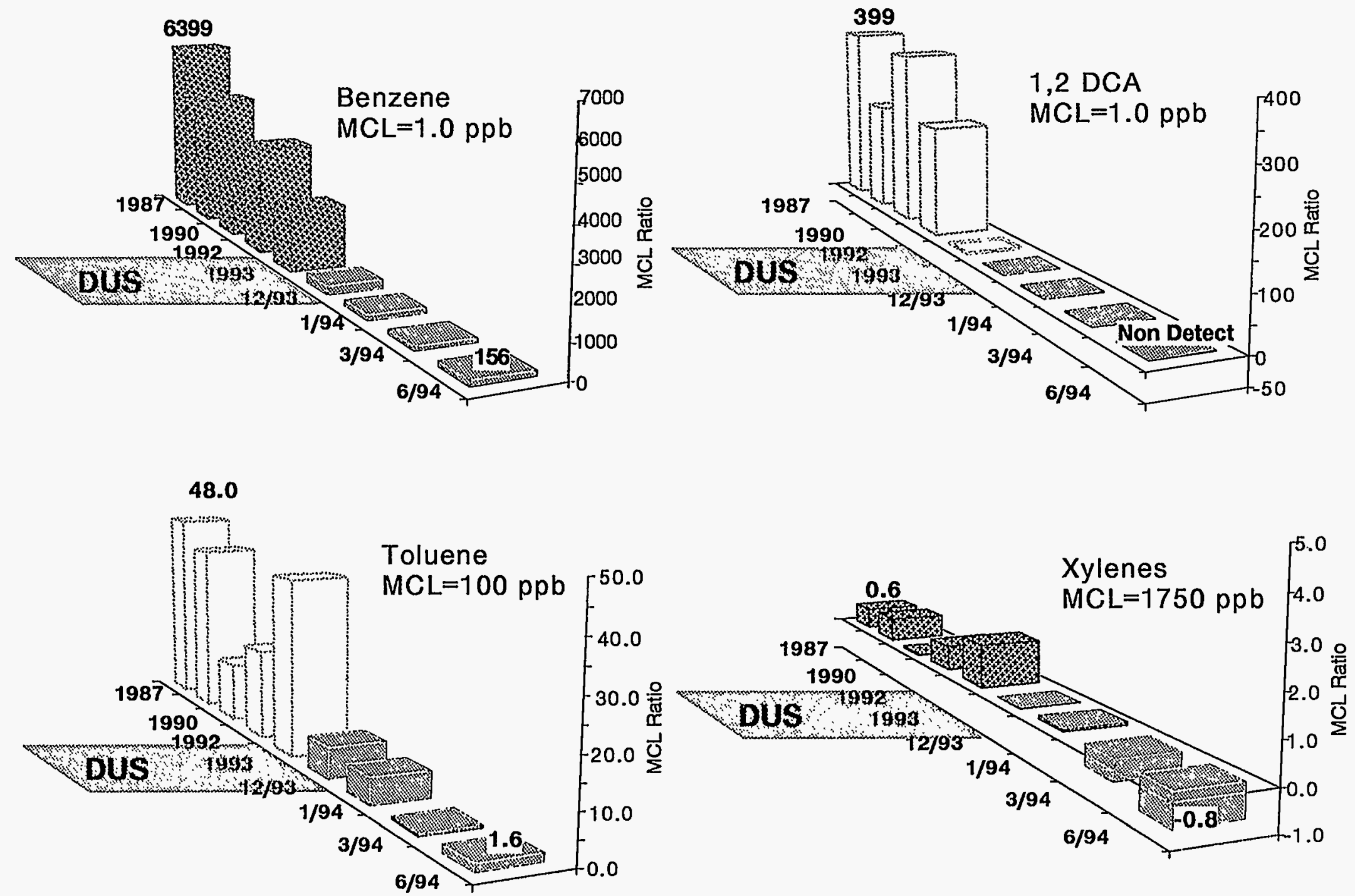

Figure 22. Dissolved groundwater contaminants at the gasoline spill site through June 1994. MCL ratio is expressed as [(contaminant concentration (ppb))/ (MCL (ppb)) ] - 1. The ratio is zero when the MCL is reached, and drops to negative values (as shown for xylene) when the MCL is exceeded. Values are given for the central extraction wells (GSW 15, 16 and GEW 808, 816). Starting and ending ratios are noted. In June, 1,2 DCA and total xylenes were below MCL, as were ethylbenzene and ethylene dibromide (not shown). Toluene was at 1.6 above its MCL, and benzene was 156 times its MCL. Data from Table 2. 


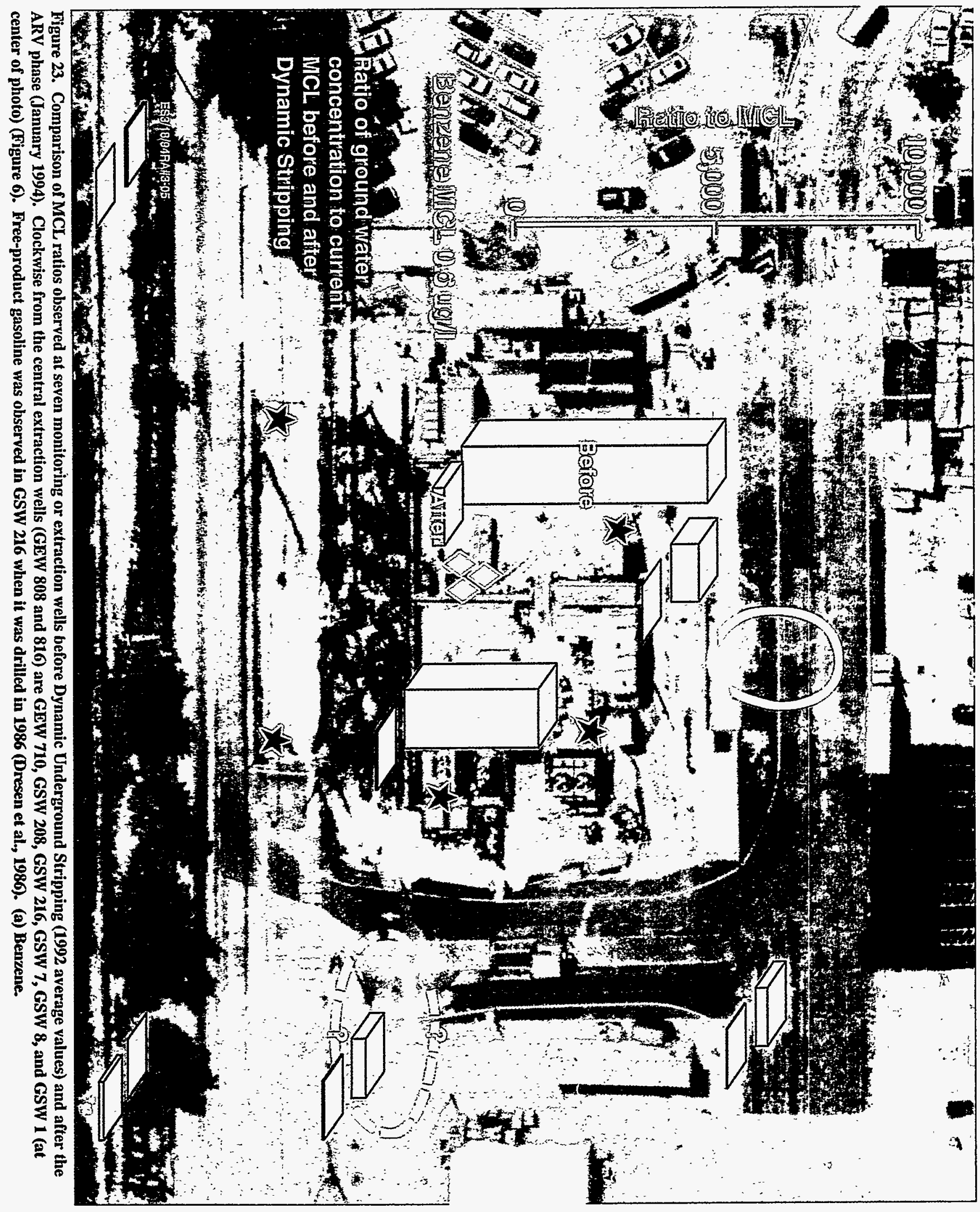




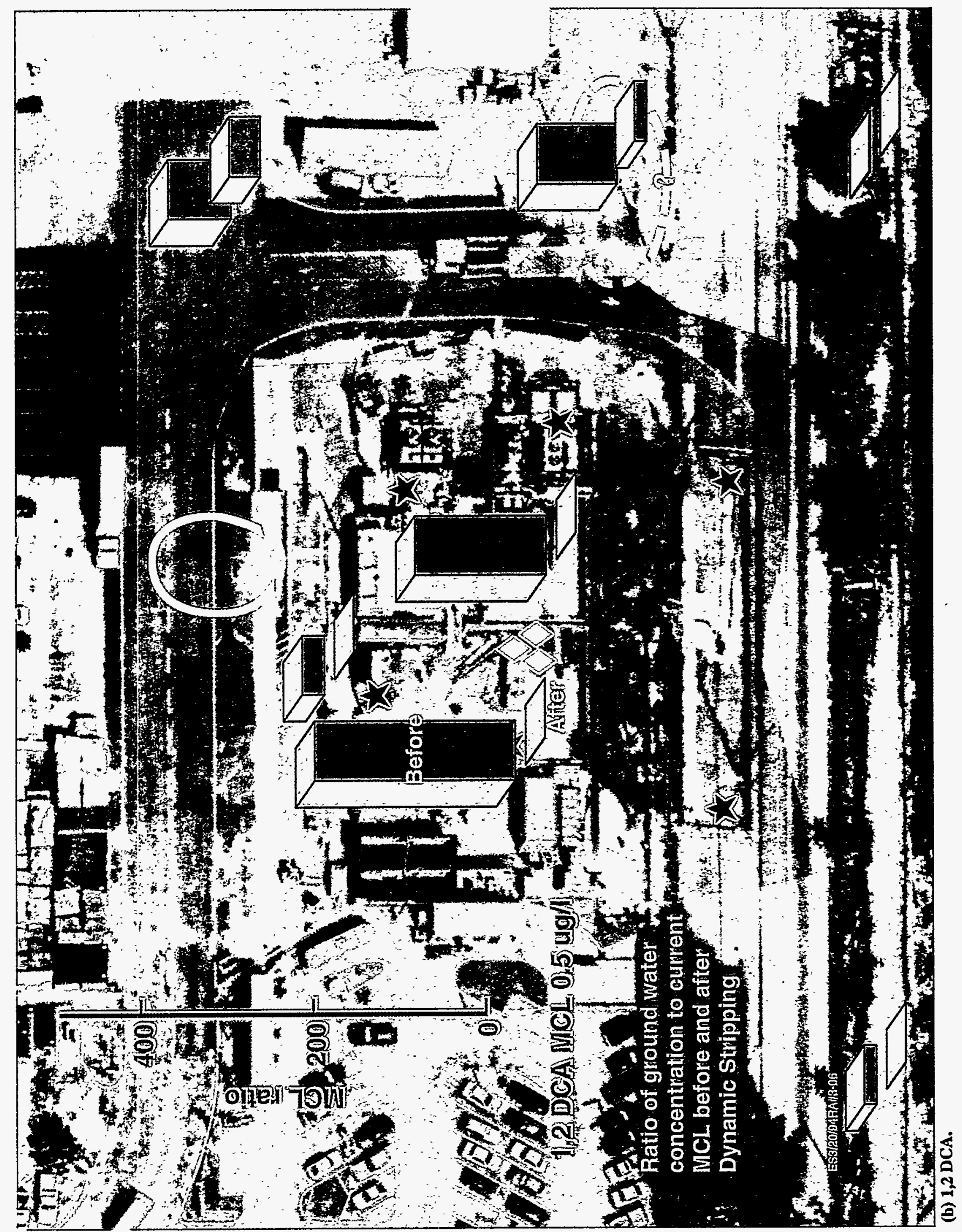




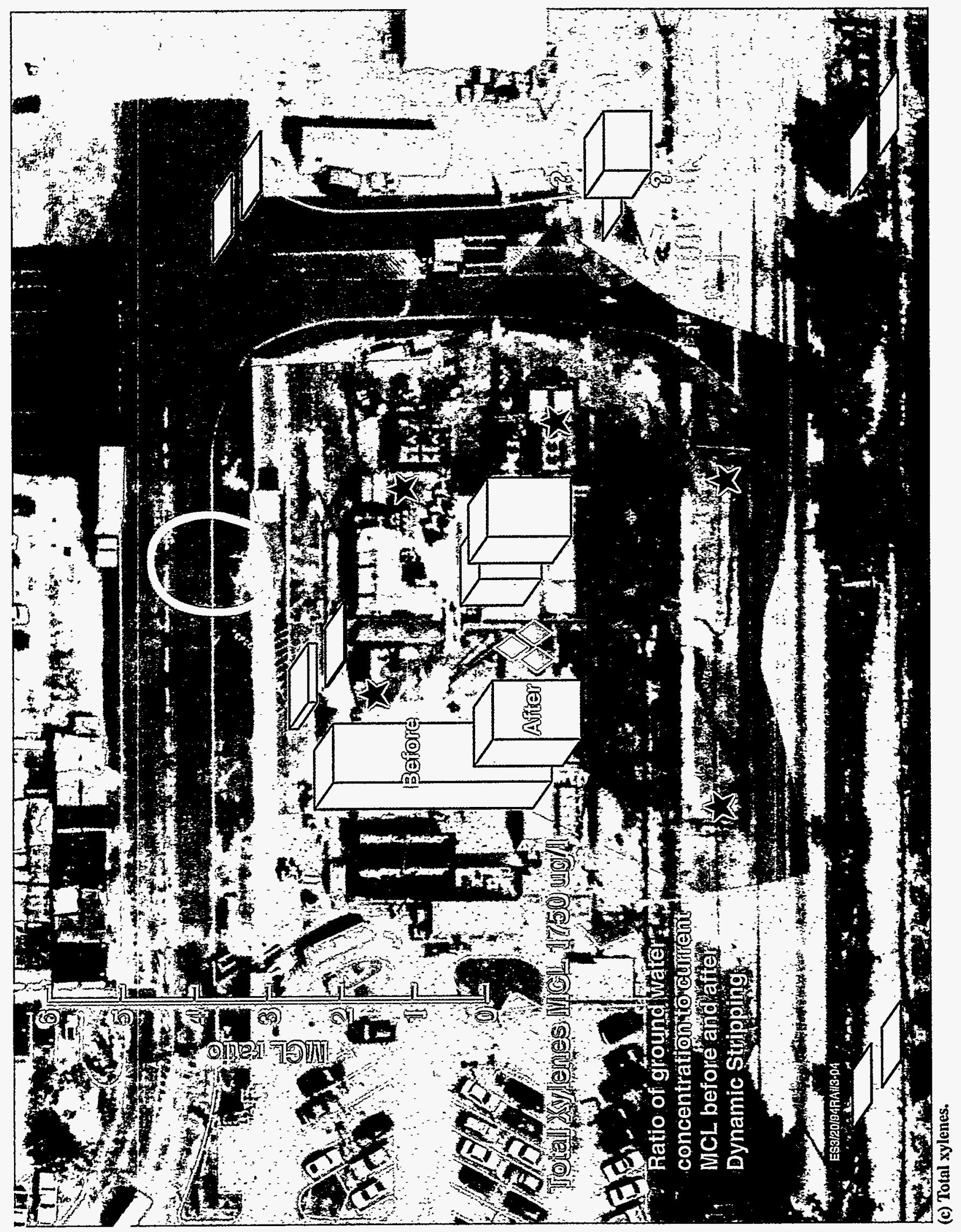


Concentrations in GSW 1 appear higher in the treated area; this value roughly matches the levels seen in the extraction wells, and reflects the same mobilization mechanisms. Ethylbenzene and ethylene dibromide are below the MCL as well.

Contaminant concentrations in the central extraction wells appear to approach the outside well values, indicating that water in the treated area is equilibrating with the untreated water as the extraction system draws water in.

The ability of Dynamic Underground Stripping to remove contaminants to such low levels in groundwater is probably indicative of the boil-off distillation mechanism described by Udell (1994a). Because volatile components are generally removed from boiling water at a massremoval rate exceeding that of the water, boiling of a small percentage of the pore water can dramatically reduce aqueous concentrations.

Udell examines the effect as a function of boiling rate, solubility, and Henry's law constants; unfortunately, solubility and Henry's law constants are not known at high temperatures for most groundwater contaminants (see data for xylene obtained as part of the ARV activities, Sweeney et al., 1994). This mechanism may be responsible for the almost instantaneous removal of 1,2 DCA from the gasoline spill site groundwater by Dynamic Underground Stripping and the dramatic decrease seen in benzene relative to xylene.

\section{Ongoing Bioremediation}

Before Dynamic Underground Stripping treatment of the gasoline spill area, a wide variety of microorganisms were actively degrading the BTEX components of the gasoline. These organisms included the dominant genus Pseudomonas originally, and after a campaign of vacuum venting in 1990-92, the genus Flavobactor was dominant. The largest populations existed in areas where gasoline was present at low concentra- tions. In the capillary fringe zone (up to $5 \mathrm{ft}$ above the water table) where gasoline concentrations were highest, there were low numbers of culturable organisms. In the central area of the spill, below the water table, oxygen concentrations were very low, and microbial activity was effectively zero.

Extensive characterization of the microbial population was conducted before heating the area, with the expectation that the soils would be sterilized and the population rebound of microorganisms in the area could be studied. Post-test drill-back in August 1993 included collection of extensive soil samples that were cultured for microorganisms both at room temperature and at $50^{\circ} \mathrm{C}$.

Although the gram-negative bacteria that had been the dominant BTEX degraders were gone, extensive microbial communities were flourishing in all samples, including those in which the soil was collected at temperatures greater than $90^{\circ} \mathrm{C}$. The dominant species were no longer bacteria, but yeasts and related organisms (Rhodotorula, Streptomyces), which had been observed in small numbers before heating. Thermophiles previously identified from environments such as the hot springs at Yellowstone National Park are important members of the new community, as well as a number of other organisms apparently representing previously unidentified species.

The rates at which this new biological community are degrading gasoline components has not yet been quantified, but it is clear that BTEX degraders (e.g., Rhodotorula) have survived and can rapidly undertake the final removal of contaminants from the groundwater. At this point, the addition of trace nutrients to the system is being considered to enhance this activity. It is hoped that final reduction of benzene levels to below the $\mathrm{MCL}$ of $1.0 \mathrm{ppb}$ can be accomplished through a combination of continued intermittent operation of the groundwater and vapor extraction systems to provide oxygen, and proper encouragement of the microbial ecosystem. 


\section{Conclusions from the Gasoline Spill Site Demonstration}

- Separate-phase gasoline has been removed from the treated area.

- A stable steam zone can be established below the water table.

- Steam injection is effective for heating permeable zones, and repeated steam passes can effectively heat small impermeable layers between.

- Dynamic Underground Stripping can reduce groundwater contamination to very low levels.

- Electrical heating is effective for heating clay zones, but higher power levels are required when extraction of hot fluids is removing heat from the formation.

- Establishing a complete steam zone in very permeable materials requires large amounts of steam; the more the better.
- Electrical resistance tomography is extremely sensitive to heating of soil and gives rapid images of steam movement between wells.

- Tilmeters accurately mapped the outer extent of the steam fronts both above and below the water table, and the footprint of steam zones emanating from individual injectors in the lower steam zone.

- Steam did not displace much liquid contaminant in a piston flow.

- Vapor recovery is the major contaminant removal mechanism.

- Gasoline is locally mobilized in heated areas and may show higher groundwater concentrations outside the treatment area even though it is not being transported.

- Treatment systems must be robust to handle the large peak extraction rates and the rapid changes in rate.

\section{References}

Adenekan, A. E., and T. W. Patzek, (1994), "Cleanup of the Gasoline Spill Area with Steam: Compositional Simulations," Dynamic Underground Stripping Project: LLNL Gasoline Spill Demonstration Report, Lawrence Livermore National Laboratory, Livermore, CA, UCRL-ID-116964, Section 5, p. 143.

Aines, R., W. Siegel, E. Sorenson, and M. Jovanovich (1994), "Gasoline Removal During Dynamic Underground Stripping: Mass Balance Calculations and Issues; Chemical Fractionation," Dynamic Underground Stripping Project: LLNL Gasoline Spill Demonstration Report, Lawrence Livermore National Laboratory, Livermore, CA, UCRL-ID-116964, Section 3, p. 447.

Barber, T. E., W. G. Fisher, and E. A. Wachter (1994a), "Characterization of the Vapor Stream at the Lawrence Livermore Dynamic Stripping Site by Differential Ultraviolet Absorption Spectroscopy," . Dynamic Underground Stripping Project: LLNL Gasoline Spill Demonstration Report, Lawrence Livermore National Laboratory, Livermore, CA, UCRL-ID-116964, Section 3, p. 397.

Barber, T. E., W. G. Fisher, and E. A. Wachter (1994b), "On-Line Monitoring of Aromatic Hydrocarbons Using a Near Ultraviolet Fiberoptic Absorption Sensor," Environmental Science and Technology (in preparation).

Bishop, D. J., et al. (1994), "Dynamic Underground Stripping Characterization Report," Dynamic Underground Stripping Project: LLNL Gasoline Spill Demonstration Report, Lawrence Livermore National Laboratory, Livermore, CA, UCRL-ID-116964, Section 2, p. 3.

Boyd, S., R. Newmark, and M. Wilt (1994), "Borehole Induction Logging for the Dynamic Underground Stripping Project, LLNL Gasoline Spill Site," Dynamic Underground Stripping Project: LLNL Gasoline Spill Demonstration Report, Lawrence Livermore National Laboratory, Livermore, CA, UCRL-ID116964, Section 4, p. 165.

Buettner, H. M., and W. D. Daily (1994a), "Cleaning Contaminated Soil Using Electrical Heating and Air Stripping," Journal of Environmental Engineering (in press).

Buettner, H. M., and W. D. Daily (1994b), "The Electrical Soil Heating Preheat Phase of Dynamic Underground Stripping," Dynamic Underground Stripping Project: LLNL Gasoline Spill Demonstration Report, Lawrence Livermore National Laboratory, Livermore, CA, UCRL-ID-116964, Section 3, p. 137. 
Carrigan, C. R., and J. J. Nitao (1994), "Development of a Predictive and Diagnostic Modeling Capability for Joule Heating," Dynamic Underground Stripping Project: LLNL Gasoline Spill Demonstration Report, Lawrence Livermore National Laboratory, Livermore, CA, UCRL-ID-116964, Section 5, p. 197.

Chute, F. S., F. E. Vermeulen, and L. G. Stevens (1987), "A Study of the Technical and Economic Feasibility of an Electric Preheat Process for In Situ Recovery from Athabasca Sands," AOSTRA Journal of Research 3 (3).

Chute, F. S., and F. E. Vermeulen (1988), "Present and Potential Applications of Electromagnetic Heating in the In Situ Recovery of Oil," AOSTRA Journal of Research 4 (1).

Cook, G. E., J. A. Oberdorfer, and S. P. Orloff (1991), Remediation of a gasoline spill by vapor extraction, Lawrence Livermore National Laboratory, Livermore, CA, UCRL-JC-108064.

Devaney, R. (1994), "Gasoline Volume Estimation," Dynamic Underground Stripping Project: LLNL Gasoline Spill Demonstration Report, Lawrence Livermore National Laboratory, Livermore, CA, UCRL-ID116964, Section 2, p. 223.

Dresen, M. D., F. Hoffman, and S. Lovejoy (1986), Subsurface Distribution of Hydrocarbons in the Building 403 Area at LLNL, Lawrence Livermore National Laboratory, Livermore, CA, UCID-20787.

Goldman, R., and K. S. Udell (1994), "Design and Development of a Temperature Measurement System to Monitor Subsurface Thermal Processes," Dynamic Underground Stripping Project: LLNL Gasoline Spill Demonstration Report, Lawrence Livermore National Laboratory, Livermore, CA, UCRL-ID116964, Section 4, p. 23.

Hunter, R. J., and R. F. Reinke (1994), "Tiltmeter Mapping of Steam Zones During Steam Injection, February-June 1993," Dynamic Underground Stripping Project: LLNL Gasoline Spill Demonstration Report, Lawrence Livermore National Laboratory, Livermore, CA, UCRL-ID-116964, Section 4, p. 185.

Jovanovich, M. C., R. E. Martinelli, M. E. Dibley, and K. L. Carroll (1994), "Process Monitoring of Organics During Dynamic Underground Stripping," Dynamic Underground Stripping Project: LLNL Gasoline Spill Demonstration Report, Lawrence Livermore National Laboratory, Livermore, CA, UCRL-ID-116964, Section 3, p. 187.

Kenneally, K. M. (1994), "Modeling Steam Locations During a Steam Injection Process for Subsurface Gasoline Spill," Dynamic Underground Stripping Project: LLNL Gasoline Spill Demonstration Report, Lawrence Livermore National Laboratory, Livermore, CA, UCRL-ID-116964, Section 5, p. 57.

Lee, K. H. (1994), "Predictive Modeling Using the STARS Code," Dynamic Underground Stripping Project: LLNL Gasoline Spill Demonstration Report, Lawrence Livermore National Laboratory, Livermore, CA, UCRL-ID-116964, Section 5, p. 169.

MacDonald, J. A., and M. C. Kavanaugh (1994), "Restoring Contaminated Groundwater: An Achievable Goal? Environmental Science and Technology 28 (8), 362A-368A.

McGee, B. C. W., F. Vermeulen, S. Schute, and H. M. Buettner (1994), "Mathematical Solution of Electromagnetic, Conductive, and Convective Transient Heat Transfer for In Situ Decontamination of Soil with Variable Electrical Properties," (in preparation).

National Research Council (1994), Alternatives for Groundwater Cleanup, National Academy Press, Washington, DC.

Nelson-Lee, J. C. (1994), "Sediment Physical and Chemical Characterization," Dynamic Underground Stripping Project: LLNL Gasoline Spill Demonstration Report, Lawrence Livermore National Laboratory, Livermore, CA, UCRL-ID-116964, Section 2, p. 47.

Newmark, R. L. (1992), Dynamic Underground Stripping Demonstration Project, Interim Engineering Report, Lawrence Livermore National Laboratory, Livermore, CA, UCRL-ID-110064.

Newmark, R. L., ed. (1994a), Dynamic Underground Stripping Project: LLNL Gasoline Spill Demonstration Report, Lawrence Livermore National Laboratory, Livermore, CA, UCRL-ID-116964.

Newmark, R. L. (1994b), "Using Geophysical Techniques to Control In Situ Thermal Remediation," Dynamic Underground Stripping Project: LLNL Gasoline Spill Demonstration Report, Lawrence Livermore National Laboratory, Livermore, CA, UCRL-ID-116964, Section 4, p. 3.

Newmark, R. L. (1994c), "Using Geophysical Techniques to Control In Situ Thermal Remediation," Proc. Symp. on Application of Geophysics to Engineering and Environmental Problems, Boston, MA, March 27-31, 1994. 
Nicholls, E. M., M. D. Dresen, and J. E. Field (1988), Proposal for Pilot Study at LLNL Building 403 Gasoline Station Area, Lawrence Livermore National Laboratory, Livermore, CA, UCAR-10248.

Ramirez, A., W. D. Daily, D. LaBreque, E. Owen, and D. Chesnut (1993), "Monitoring an Underground Steam Injection Process Using Electrical Resistance Tomography," Water Resources Research 29, 73-87.

Ramirez, A., J. Beatty, J. Carbino, W. Daily, and R. Newmark (1994), "Monitoring Thermal Treatment Processes Using Electrical Resistance Tomography," Dynamic Underground Stripping Project: LLNL Gasoline Spill Demonstration Report, Lawrence Livermore National Laboratory, Livermore, CA, UCRL-ID-116964, Section 4, p. 69.

Siegel, W. H. (1994), “Design, Construction, and Operation of Dynamic Underground Stripping Facilities at Lawrence Livermore National Laboratory," Dynamic Underground Stripping Project: LLNL Gasoline Spill Demonstration Report, Lawrence Livermore National Laboratory, Livermore, CA, UCRL-ID116964 , Section 3, p. 3.

Sorenson, E., and W. H. Siegel (1994), "Treatment Facility F," Dynamic Underground Stripping Project: LLNL Gasoline Spill Demonstration Report, Lawrence Livermore National Laboratory, Livermore, CA, UCRL-ID-116964, Section 3, p. 123.

Sweeney,.J. J., M. H. Buettner, C. R. Carrigan, C. S. Chamberlain, A. B. Copeland, M. A. Hernandez, G. B. Hudson, M. C. Jovanovich, K. C. Knauss, R. M. McNairy, W. H. Siegal, and E. A. Sorenson (1994), "Treatment Facility F: Accelerated Removal and Validation Project," Dynamic Underground Stripping Project: LLNL Gasoline Spill Demonstration Report, Lawrence Livermore National Laboratory, Livermore, CA, UCRL-ID-116964, Section 6, p. 3.

Thorpe, R. K., W. F. Isherwood, M. D. Dresen, and P. Webster-Scholten, eds. (1990), CERCLA Remedial Investigations Report for the LLNL Livermore Site, Lawrence Livermore National Laboratory, Livermore, CA, UCAR-10299.

Udell, K. S. (1994a), "Heat and Mass Transfer in Cleanup of Toxic Waste," Advances in Heat Transfer Research, C. L. Tien, ed., Environmental and Engineering Geophysical Society, Englewood, CO, pp. 195-211.

Udell, K. S. (1994b), "Predictions of Recovery of Gasoline from the LLNL Gasoline Spill Site with Dynamic Underground Stripping," Dynamic Underground Stripping Project: LLNL Gasoline Spill Demonstration Report, Lawrence Livermore National Laboratory, Livermore, CA, UCRL-ID-116964, Section 5, p. 45.

Udell, K. S. (1994c), "Thermally Enhanced Removal of Liquid Hydrocarbon Contaminants from Soils and Groundwater," Dynamic Underground Stripping Project: LLNL Gasoline Spill Demonstration Report, Lawrence Livermore National Laboratory, Livermore, CA, UCRL-ID-116964, Section 5, p. 5.

Udell, K. S. (1994d), "Thermally Enhanced Removal of Non-Aqueous-Phase Liquid Contaminants from Soils and Groundwater," Subsurface Restoration, C. H. Ward, ed. (in press).

Udell, K. S., and L. D. Stewart (1989), "Mechanisms of In Situ Remediation of Soil and Groundwater Contamination by Combined Steam Injection and Vacuum Extraction," Symp. on Thermal Treatment of Radioactive and Hazardous Waste, AIChE Annual Meeting, November 6, San Francisco, CA.

Udell, K. S. and L. D. Stewart (1990), "Combined Steam Injection and Vacuum Extraction for Aquifer Cleanup," Conf. of the International Association of Hydrogeologists, April 18-20, Calgary, Alberta, Canada.

Udell, K. S., N. Sitar, J. R. Hunt, and L. D. Stewart (1991), Process for In Situ Decontamination of Subsurface Soil and Groundwater, United States Patent 5,018,576.

Vaughn, P. J., K. S. Udell, and M. J. Wilt (1993), "The Effects of Steam Injection on the Electrical Conductivity of an Unconsolidated Sand Saturated with a Salt Solution," J. Geophysical Research 98 (B1), 509-518. 